\title{
Proceedings of the 1st Army Installation Waste to Energy Workshop
}

\section{US Army Corps of Engineers $S_{\circledast}$} Engineer Research and Development Center

Franklin H. Holcomb, René S. Parker, Thomas J. Hartranft, Kurt Preston, Harold R. Sanborn, and Philip J. Darcy

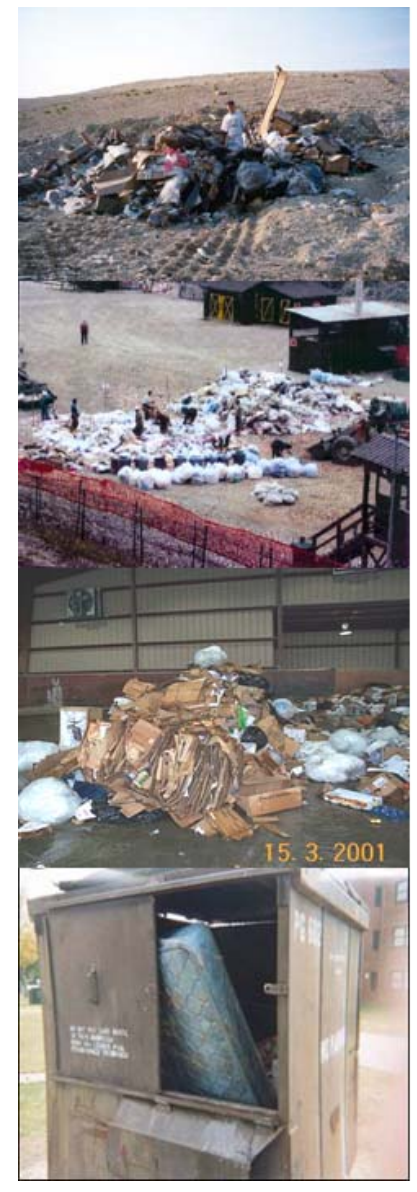

\section{Waste as Integral Part of Distributed Power Architecture}

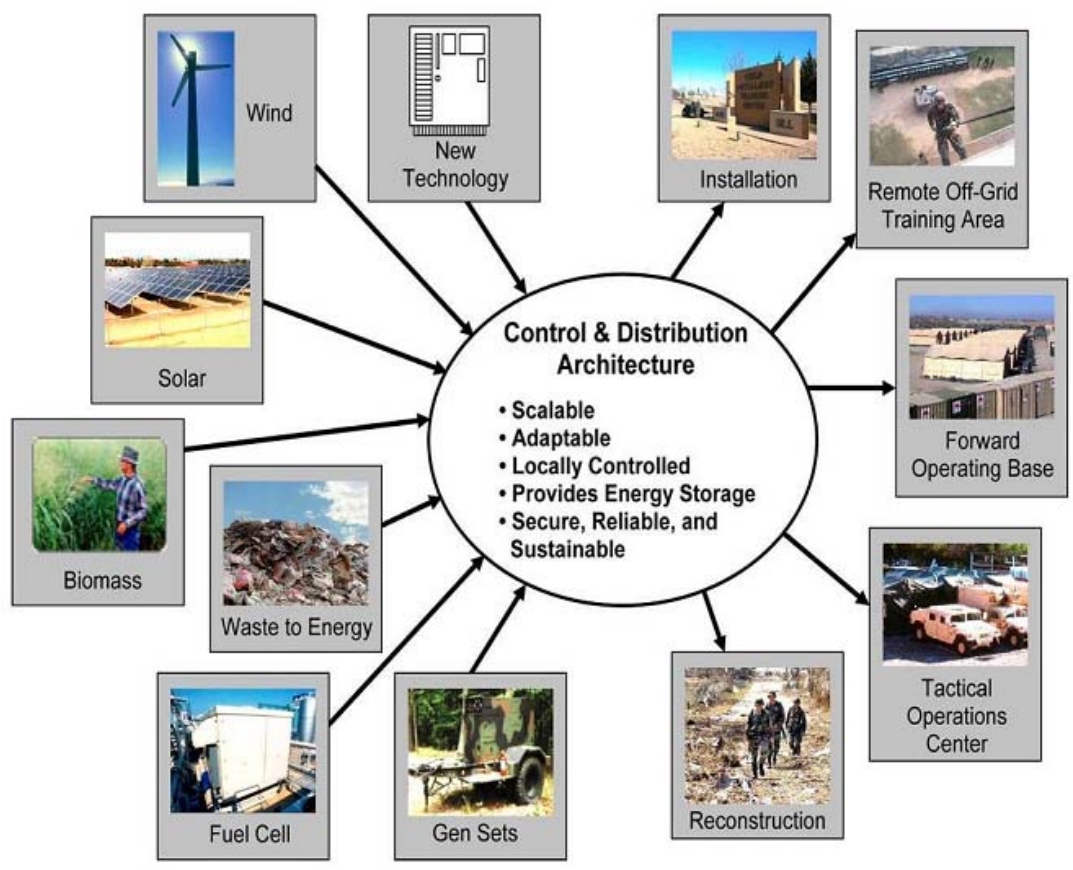




\section{Proceedings of the 1st Installation Waste to Energy Workshop}

Franklin H. Holcomb

Construction Engineering Research Laboratory (CERL)

U.S. Army Engineer Research and Development Center

2902 Newmark Dr.

Champaign, IL 61824

René S. Parker

Select Engineering Services (SES)

1544 Woodland Park Ave. Suite 310

Layton, UT 84041

Thomas J. Hartranft

Construction Engineering Research Laboratory (CERL)

U.S. Army Engineer Research and Development Center

2902 Newmark Dr.

Champaign, IL 61824

Final Report

Approved for public release; distribution is unlimited.

\author{
Kurt Preston \\ U.S. Army Research Office (ARO) \\ P.O. Box 12211 \\ Research Triangle Park, NC 27709-2211 \\ Harold R. Sanborn \\ U.S. Army Tank Automotive Research Development \\ and Engineering Center (TARDEC) \\ National Automotive Center (NAC) \\ 6501 E. 11 Mile Road \\ Warren, MI 48397-5000 \\ Philip J. Darcy \\ Benét Laboratories \\ 1 Buffington Street \\ Watervliet, NY 121189-4050
}




\begin{abstract}
This first-ever waste to energy (WTE) workshop gathered Army environmental and energy subject matter experts to explore WTE at the installation and forward operating level. Historically, the Army environmental community has focused on solid waste disposal and the energy community on energy efficiency and power delivery, with no orchestrated integration of the two. The Energy Branch of the U.S. Army Engineer Research and Development Center, Construction Engineering Research Laboratory has been investigating WTE opportunities, and has found little Army analysis on WTE system providers' many claims. The goals of this workshop were to share information, spread visibility on current efforts, explore the potential of WTE technologies for military installations, and potentially launch working groups to further implementation of installation WTE technologies. The Army has many requirements, goals, and recommendations applicable to DoD installations, facilities, and energy. WTE technologies are being developed for deployed forces, and have been used somewhat at fixed installations. Studies have focused on the types, amounts, and "burdened" costs of battlefield wastes, but less so on installation waste streams. Workshop participants concluded that greater use or development of WTE technologies may help fixed installations meet requirements and goals, but data is lacking to adequately characterize the potential.
\end{abstract}

DISCLAIMER: The contents of this report arenot to be used for advertising, publication, or promotional purposes. Citation of trade names does not constitute an official endorsement or approval of the use of such commercial products. All product names and trademarks cited are the property of their respective owners. The findings of this report are not to be construed as an official Department of the Army position unless so designated by other authorized documents. 


\section{Executive Summary}

\section{Problem statement}

Army and DoD fixed installations generate many waste streams, including biomass, municipal solid waste (MSW), construction and debris (C\&D) waste, wastewater, etc. Managing these waste streams generally involves collection, transportation, processing, and ultimately reduction or disposal. Unit operations associated with ultimate disposal generally includes a re-use or recycling effort, followed by landfilling, incineration, or some other form of ultimate disposal. Often these waste streams possess an energy (Btu) content, and to the extent that they do, it may be possible and desirable to transform the energy to a form that will allow for the performance of work toward the ultimate state of disposal.

Approaches to transforming or capturing the energy content of the waste include:

1. Incineration or other thermal oxidation for energy release

2. Physical and/ or chemical preprocessing followed by conversion into a solid fuel for storage and later use

3. Chemical conversion into a gaseous or liquid fuel to be used in a generator, fuel cell, etc. for electricity production and resultant work.

The benefits of WTE processes include increased energy security (an alternative energy source that can be stored as fuel or used in situ), the potential for renewable energy generation (when renewable waste streams are involved), and the potential for lower emissions (when using less polluting methods of waste reduction or disposal).

\section{Energy considerations}

The laws of thermodynamics dictate while the sum of net heat supplied to the system and the net work done by the system is equal to zero, it is impossible to convert heat into work with 100 percent efficiency. In the process of releasing stored energy or heat to work, some released heat will be unusable. The extent to which useable energy will be released and can be captured to perform work depends on the type of waste, quantity, and process employed for reducing/ eliminating the waste. 
From the presentations and discussions during the workshop, it was found that some WTE conversion systems produced a net export of useable energy and some WTE conversion systems were a net consumer of energy during the waste reduction/ disposal process. While the systems described in the latter case are not as desirable as the systems in the former case from a WTE standpoint, the latter case may be more desirable from the standpoint of reducing or eliminating the waste stream. In short, the workshop determined that waste material conversion for energy recovery may or may not be the sole driver for considering a WTE conversion processes. Volume reduction, elimination of putrescibles or vectors, and associated force protection benefits may provide important concurrent benefits.

For example, the predominantly wood and plastic waste in deployed encampments is often burned or incinerated in situ. In this case, some of the energy produced (in the form of heat) could be directed to an external process (such as an electric water heater for showers), which would offset or eliminate the energy (electricity for the water heater) requirement of the aforementioned external process. Other waste conversion processes, such as plasma arc decomposition, typically require an energy input to reduce/ eliminate the waste, and these processes generally do not produce any useable energy output.

\section{Drivers and economics for fixed installations vs. deployed encampments}

Different drivers exist for the potential use of waste conversion processes for fixed installations versus deployed encampments. Waste processing itself is a very important goal for the fixed installation environmental community that may or may not result in "excess" energy delivery for other purposes. Because of rising costs of labor, transportation, and tipping fees along with solid waste policy mandates, installations need to minimize waste generation and increase waste diversion from landfills through reuse, recycling, and alternative treatment options. For forward operating bases (FOBs), tactical operation centers (TOCs), or any encampment that is in a deployed (i.e., not a fixed installation) configuration, reduction/ elimination of the waste is considered the desirable end state, especially from a force protection point of view.

An economic case for waste reduction/ elimination processes for forward deployments can usually be made when compared to the high cost of fuel in the battlefield. The delivered cost of fuel to the battlefield is often re- 
ferred to as the "burdened" cost of fuel, which includes all of the logistical costs of transporting, protecting, and storing the fuel. These costs have been documented to range from $\$ 10 /$ gallon up to $\$ 400 /$ gallon depending on the delivery method (ship, truck, or aircraft). Fuel convoys traveling into a theater of operations are often targeted by enemy forces, and the burdened cost of this delivered fuel is now recognized to include human casualties. In today's climate, any processes or efficiencies that result in a reduction in fuel usage in the battlefield are of great interest to the DoD.

\section{Army and DoD impact assessment}

From the discussions in the workshop, the potential impacts (whether economic or otherwise) of waste reduction/ elimination processes at fixed installations are not as well defined or as studied as the aforementioned deployed encampment scenarios. While Army installations have a means to report their annual waste amounts and remediation costs (via the U.S. Army Solid Waste Annual Reporting System (SWARS) database), the current data available is lacking and incomplete. Minimizing waste generation or the burdens of waste treatment will result in less energy being consumed. However, while WTE technologies can provide a source of renewable energy, that energy is of low quality and unreliable because it is dependent on the waste stream. Better renewable energy options are solar, wind, geothermal, and perhaps hydroelectric.

An estimate of the "burdened" cost of waste, to include the costs of collection, transportation, processing, environmental attributes such as compliance, and reduction or disposal would be a helpful metric for an economic impact analysis of installation WTE systems. The energy and environmental offices at installations will need to work together to quantify the "burdened" costs of waste, and quantify the benefits from any proposed WTE efforts.

\section{Project financing and potential funding options}

For energy projects in particular, Army and DoD fixed installations are becoming increasingly reliant on third party financing through contractual mechanisms such as Energy Savings Performance Contracts (ESPCs), Enhanced Use Leases (EULs), or Power Purchase Agreements (PPAs). Demonstration funding is available in limited amounts through the DoD Energy Conservation Investment Program (ECIP), DoD Environmental Security Technology Certification Program (ESTCP), the Army's Installation Technology Transition Program (ITTP), and others. While individual 
projects can be funded or financed on a case-by-case analysis, the broader potential impact of fielding WTE systems or processes Army or DoD wide cannot be projected without detailed baseline data.

\section{Group conclusions and next steps}

During the group discussion at the end of the workshop, a number of conclusions and suggestions were brought forward. The following are particularly relevant:

- A study to estimate the "burdened" cost of waste for particular waste streams across the Army and DoD would be beneficial to assess the potential impact of WTE systems. LTC Mark Smith of USMA West Point suggested this would be a good cadet Capstone project, if another agency was willing to provide sponsorship and funding.

- A simple waste conversion screening tool/application database would be helpful to provide information on WTE technologies. This database could include additional information to give installations interim guidance on available contracting mechanisms. Technology information should include topics such as feedstock, conversion process, operational and maintenance requirements, mobility, capital costs, end-use products, and potential economic, energy, and environmental impacts.

- To reduce duplication and promote leveraging among the Services, a knowledge database of planned or implemented WTE projects or efforts should be developed. ERDC-CERL offered a web page for the collection of such information at http:// dodfuelcell.cecer.army.mil/rd/ Waste-to-Energy.php.

- There should be a $2^{\text {nd }}$ installation waste-to-energy workshop. This workshop should include additional case studies of successful implementations of WTE projects at fixed installations, with a discussion of the various financing mechanisms that were used. Invitations should be made to both installation energy and environmental managers to ensure that their respective perspectives are voiced and understood. 


\section{Contents}

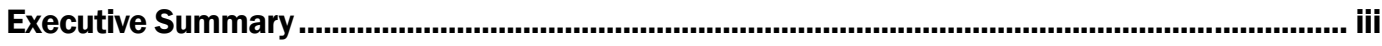

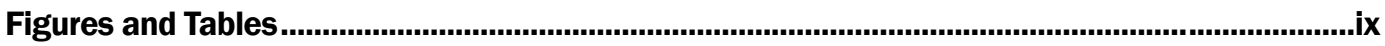

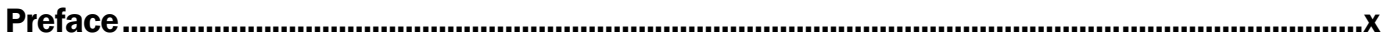

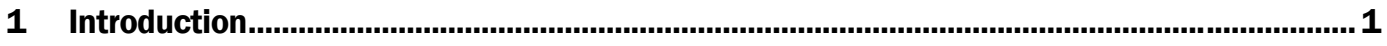

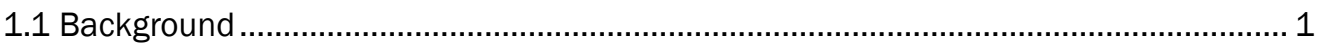

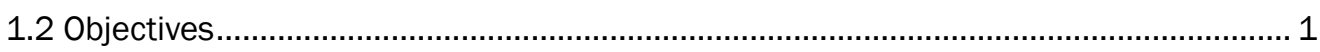

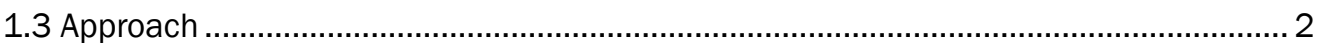

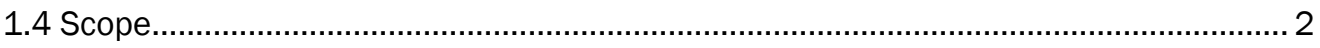

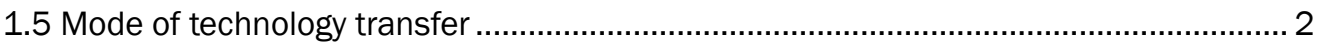

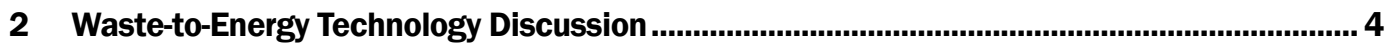

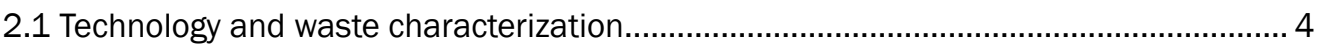

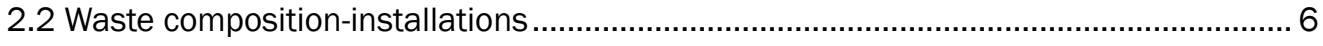

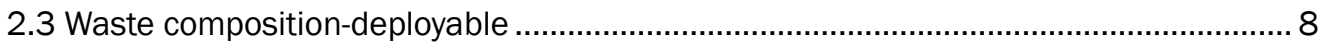

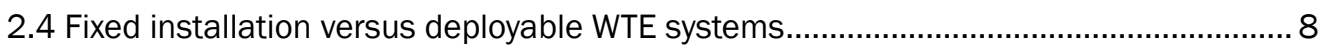

2.5 Project financing and potential funding options ...................................................... 10

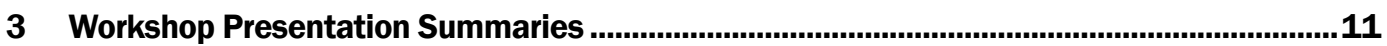

3.1 installation waste streams defined/recoverable energy ........................................... 11

3.2 WTE technologies and commercialization status ..................................................... 11

3.3 Demonstration of solid waste reduction systems for Army operations .........................13

3.4 Fort Detrick Enhanced Use Lease (EUL) energy plant............................................... 13

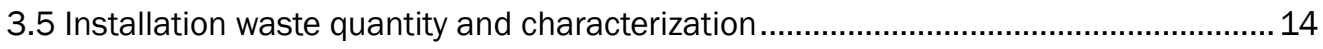

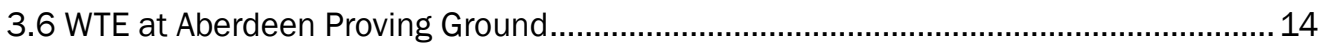

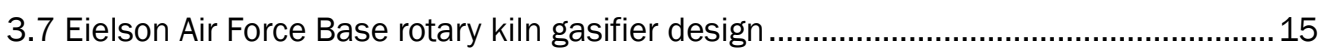

3.8 Super Critical Water Oxidation (SCWO) WTE technology ........................................... 15

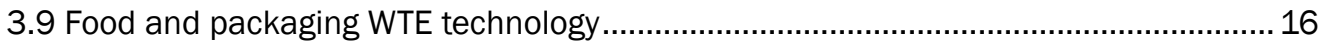

3.10 CONsolidated and Deployable Omni-Recycling (CONDOR)....................................... 17

3.11 Tactical Garbage to Energy Refinery (TGER) ......................................................... 17

3.12 Military encampment waste to electrical power system/wrap-up .............................. 18

3.13 Where do we go from here? Opportunities, technology gaps, formalizing relationships, wrap-up and action items .......................................................... 18

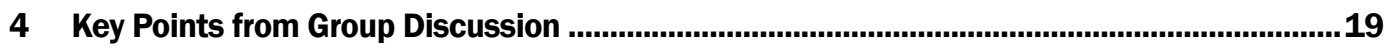

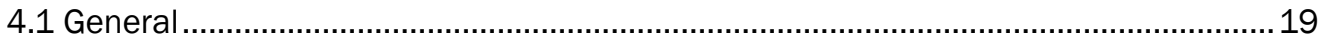

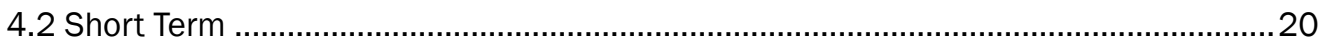

4.3 Intermediate.

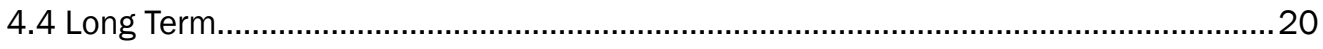

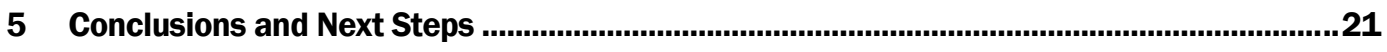

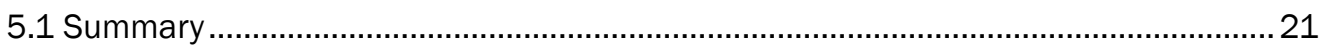


5.2 Recommendations and next steps .................................................................... 21

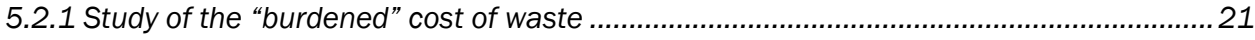

5.2.2 Waste conversion screening tool/application database ................................................ 22

5.2.3 Central repository for WTE information........................................................................ 22

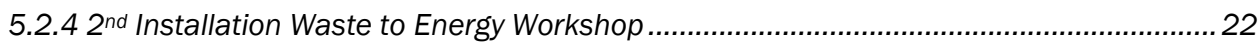

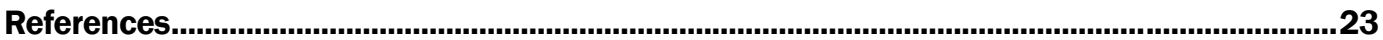

Appendix A: Waste-to-Energy Workshop Background Document................................................26

Report Documentation Page .....................................................................................................44 


\section{Figures and Tables}

\section{Figures}

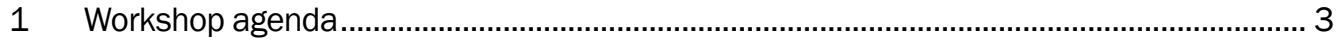

2 Biomass conversion pathways (National Renewable Energy Laboratory) ............................ 4

3 Small-scale gasification................................................................................................ 6

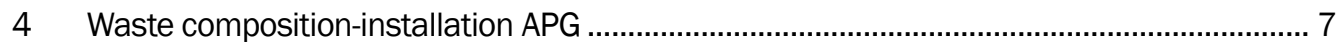

5 Solid waste generated by the Army IMA/MACOMs in the 50 United States, FY2007

A1 Federal facilities within 15 miles of a candidate landfill (Source: http://www1.eere.energy.gov/femp/pdfs/bamf_landfill.pdf)......................................................32

A2 Solid Waste Composition-Aberdeen Proving Ground (Source: Solid Waste Characterization at an Army Facility, USACHPPM, Ground Water and Solid Waste Program 2007) 32

A3 Solid waste stream characterization for deployed Army units (Source: An Analysis of the Energy Potential of Waste in the Field, LMI, February 2004) ..................................33

A4 Solid waste management hierarchy (Source: Environmental Protection Agency)...............34

A5 Preferred gasification technologies at different scales (Source: Larson, Eric D., “Small-Scale Gasification-Based Biomass Power Generation," January 1998.)................ 35

A6 Biomass conversion pathways (Source: National Renewable Energy Laboratory) .............36

A7 Gasifier types (Source: National Renewable Energy Laboratory)........................................ 40

\section{Tables}

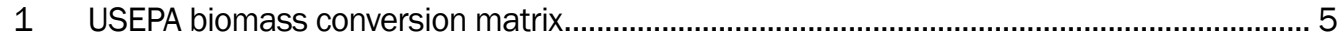

2 Waste composition at selected installations................................................................... 9 


\section{Preface}

The Installation Waste to Energy Workshop was jointly organized by the Construction Engineering Research Laboratory, Army Research Office (ARO), U.S. Army Tank Automotive Research, Development and Engineering Center, National Automotive Center (TARDEC-NAC), and Benét Laboratories as an independent initiative conducted for the benefit of Army and DoD installations and policy leaders. This Technical Report documents the proceedings of that workshop.

The report was accomplished by the Energy Branch (CF-E) of the Facilities Division (CF), Construction Engineering Research Laboratory (CERL), with textual input from Select Engineering Services (SES), ARO, TARDECNAC, and Benét Laboratories The CERL principal investigators were Franklin H. Holcomb and Dr. Thomas Hartranft. Dr. Kurt Preston was the Principal Investigator from ARO; Mr. Harold Sanborn was the Principal Investigator from TARDEC-NAC; and Mr. Philip Darcy was the Principal Investigator from Benét Laboratories. The authors would like to acknowledge the contributions of Dr. Kurt Preston and ARO for hosting and facilitating the $1^{\text {st }}$ Installation Waste to Energy Workshop, as well as Ms. Rene Parker of SES for developing a read ahead document for the workshop and for documenting the discussions during the workshop. The authors also acknowledge and appreciate the contributions of all presenters and other participants at the workshop. Martin J. Savoie is the Technical Director for the Installations business area. Dr. Thomas Hartranft is Chief, CF-E, and L. Michael Golish is Chief, CF. The Director of ERDC-CERL is Dr. Ilker R. Adiguzel.

CERL is an element of the U.S. Army Engineer Research and Development Center (ERDC), U.S. Army Corps of Engineers. The Commander and Executive Director of ERDC is COL Gary E. J ohnston, and the Director of ERDC is Dr. James R. Houston. 


\section{Introduction}

\subsection{Background}

The Army has a number of requirements, goals, and recommendations that are applicable to DoD installations, facilities, energy and the environment. Examples include the 2005 Energy Policy Act, 2005, Army Energy Strategy, Executive Order 13423, Energy Independence and Security Act of 2007 (EISA), FY07 Army Environmental Requirements and Technology Assessments (AERTA), and the recently released Defense Science Board recommendations. Within these requirements is a need to produce power on site from renewable resources (which include solar, wind, biomass, landfill gas, and nonhazardous municipal solid waste), while minimizing waste generation and increasing the rate of diversion of waste from landfills.

The AERTA Report focuses on contingency operations, but also has applicability to fixed installation. The report establishes the "Army's environmental quality technology requirements representing the critical environmental technology needs for accomplishing the Army's mission while minimizing impact to the environment." Specifically, this report contains requirements pertaining to Waste Management Utilizing Waste Characteristics (CM-6-07-02) and Zero Footprint Base Camps (PP-5-07-01). The first requirement listed above identifies the Army's need to better manage waste within contingency operations and to find ways to either completely consume, re-use, or leave behind benign waste. The latter requirement (Zero Footprint Base Camps) identifies the need to employ a multi-step process to use waste to achieve desired reduction in environmental impacts, to reduce both the logistics footprint and the operations and sustainment costs associated with base camp operations. One of the solutions put forth under this requirement is the use of waste to energy (WTE).

Force protection challenges have led to the development of WTE technologies for deployed forces, and increased renewable energy production goals have encouraged use of WTE projects at fixed installations.

\subsection{Objectives}

The objectives of this workshop were to share information, spread visibility of current efforts, and explore the potential of WTE technologies for 
Army (and Department of Defense) installations, and to potentially launch working groups to further advance the implementation of installation WTE technologies.

\subsection{Approach}

The workshop was held at the Army Research Office (ARO) in Research Triangle Park, NC over a 2-day period with presentations from subject matter experts and government stakeholders with current WTE projects. The end of the second day was set aside as a wrap-up and discussion of next steps.

Figure 1 shows the workshop agenda, hyperlinked to the presentation files. Thirty-two attendees participated, from CERL, ARL, TARDEC, Benét Laboratories, Aberdeen Proving Ground (APG), U.S. Air Force-Advanced Power Technology Office (APTO), Natick Labs, Fort Bragg, Fort Detrick, Fort Riley, Pacific Northwest National Laboratory (PNNL), U.S. Military Academy (USMA) West Point, North Carolina State Solar Center, Sierra Army Depot, Defense Logistics Agency (DLA), Air Force Research Laboratory (AFRL), Assistant Chief of Staff for Installation Management (ACSIM), Headquarters-Installation Management Command (HQ IMCOM), U.S. Army Engineer School Directorate of Environmental Integration (USAES-DEI), and the Army Environmental Command (AEC).

A WTE read-ahead document, authored by René Parker of SES, was provided to participants before the workshop, which included background material, definitions, requirements, and information on energy conversion pathways. Appendix A includes the entire read-ahead document.

\subsection{Scope}

This workshop was jointly organized by CERL, ARO, TARDEC, and Benét Laboratories and was limited to government stakeholders and contractors acting in direct support of government stakeholders. This limitation was meant to allow government stakeholders and those in direct support to participate in a focused, open discussion and to share experiences about the direction the Army and DoD was heading related to waste to energy.

\subsection{Mode of technology transfer}

This report will be made accessible through the World Wide Web (WWW) at URL: http://dodfuelcell.cecer.army.mil//rd/Waste to energy.php 


\begin{tabular}{|c|c|c|c|c|}
\hline \multicolumn{5}{|c|}{ Detailed Agenda \& Speakers, Day One } \\
\hline \multicolumn{3}{|c|}{ Tuesday, 20 May 2008} & & $\begin{array}{l}\text { Installation Waste to Energy } \\
\text { Workshop Day One }\end{array}$ \\
\hline Start & End & Time & Topic & Speaker \\
\hline $12: 45$ & $13: 00$ & $0: 15$ & Arrive ARO / Sign in & \\
\hline $13: 00$ & $13: 20$ & $0: 20$ & Welcome / Introductions & All \\
\hline $13: 20$ & $13: 40$ & $0: 20$ & Overview of Meeting and Expectations & Kurt Preston, ARO \\
\hline $13: 40$ & $14: 00$ & $0: 20$ & Installation Waste Streams Defined / Recoverable Energy & Rene Parker, SES \\
\hline $14: 00$ & $14: 50$ & $0: 50$ & WTE Technologies and Commercialization Status & Mike Warwick, PNNL \\
\hline $14: 50$ & $15: 15$ & $0: 25$ & Demo of Solid Waste Reduction Systems for Army Operations & Thomas Guinivan, AEC \\
\hline $15: 15$ & $15: 45$ & $0: 30$ & Fort Detrick Enhanced Use Lease (EUL) Energy Plant & COL Don Archibald, CHPPM \\
\hline $15: 45$ & $16: 10$ & $0: 25$ & Installation Waste Quantity \& Characterization & Steve Cosper, ERDC-CERL \\
\hline $16: 10$ & $16: 35$ & $0: 25$ & Waste to Energy at Aberdeen Proving Ground, MD & Daniela Caughron, APG \\
\hline $16: 35$ & $16: 55$ & $0: 20$ & Eielson AFB Rotary Kiln Gasifier Design & Tom Davison, APTO \\
\hline $16: 55$ & $17: 00$ & 0:05 & End of Day One, Discussion Topics for Day Two & All \\
\hline
\end{tabular}

Detailed Agenda \& Speakers, Day Two

\begin{tabular}{|c|c|c|c|c|}
\hline \multicolumn{3}{|c|}{ Wednesday, 21 May 2008} & & $\begin{array}{l}\text { Installation Waste to Energy } \\
\text { Workshop Day Two }\end{array}$ \\
\hline Start & End & Time & Topic & Speaker \\
\hline $8: 15$ & $8: 20$ & 0:05 & Review of Day One Discussions \& Preview of Day Two & Kurt Preston, ARO \\
\hline 9:45 & 10:00 & $0: 15$ & Break & \\
\hline $10: 00$ & 10:20 & $0: 20$ & CONsolidated and Deployable Omni-Recycling (CONDOR) & Seth Foulkes, CTC / AFRL \\
\hline $10: 20$ & 10:30 & $0: 10$ & Short discussion of Tactical Garbage to Energy Refinery (TGER) & \\
\hline
\end{tabular}

Figure 1. Workshop agenda. 


\section{Waste-to-Energy Technology Discussion}

\subsection{Technology and waste characterization}

The two primary drivers that determine the appropriate WTE technology are: (1) the quantity of waste and (2) the composition of the waste. Depending on the quantity and composition, various conversion technologies can be used to produce a range of end products. Figure 2 highlights the three major conversion processes: (1) Thermal, (2) Biological, and (3) Physical/Chemical.

Table 1 lists conversion technologies, associated feedstocks, and the end products of each. Within the thermal conversion pathways, there has been much attention placed on the gasification process that either produces a syngas or producer gas. If pure oxygen is introduced to the gasification process, this will result in a syngas (higher levels of carbon monoxide and hydrogen) whereas if air is introduced, a producer gas will be produced. Syngas, having higher levels of carbon monoxide and hydrogen, offers many options for the development of end products ranging from heat and power to liquid fuels and chemicals.

Figure 3 shows the most suitable gasifier type for the amount of energy produced. It is important to match the waste composition, quantity and end use to the conversion technology.

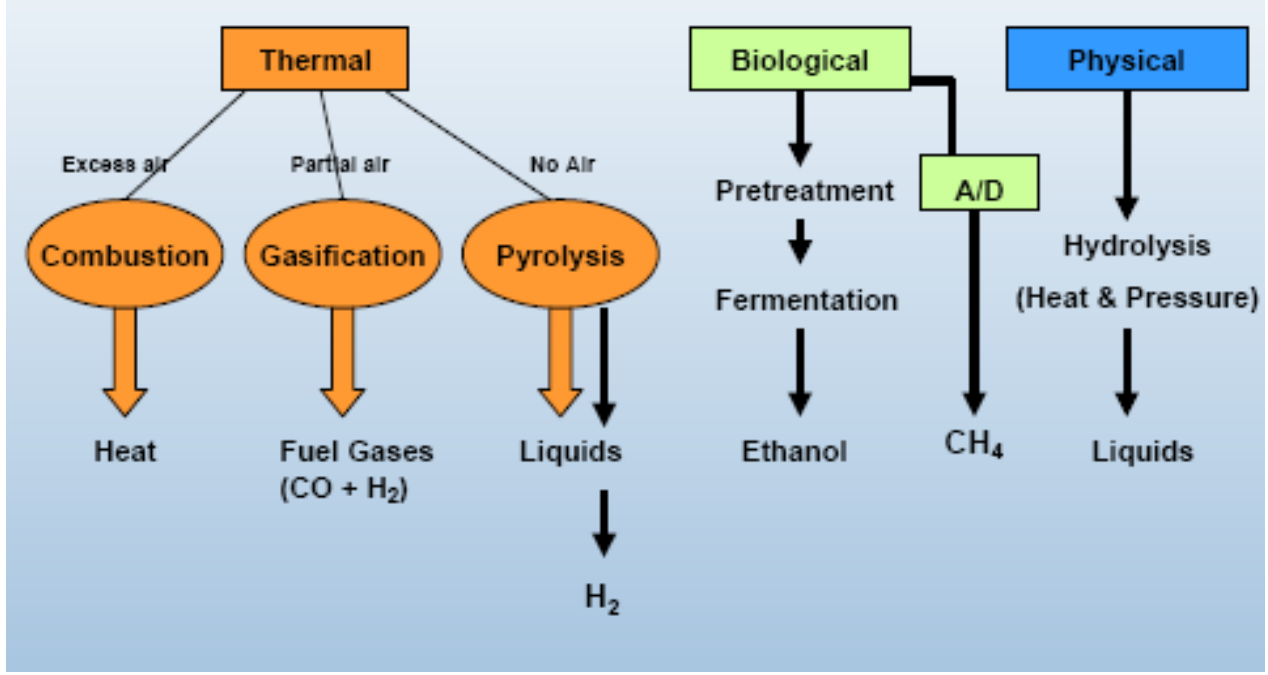

Figure 2. Biomass conversion pathways (National Renewable Energy Laboratory). 
Table 1. USEPA biomass conversion matrix.

\begin{tabular}{|c|c|c|c|c|c|}
\hline & & \multicolumn{2}{|r|}{$\begin{array}{l}\text { 1. Biomass Conversion } \\
\text { Technology }\end{array}$} & 2. Feedstocks & 3. Products \\
\hline \multirow{5}{*}{ 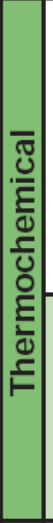 } & \multirow{3}{*}{ 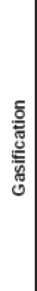 } & 这 & $\begin{array}{l}\text { Downdraft Co-Current Fixed Bed } \\
\text { Updraft Co-Current Fixed Bed } \\
\text { Cross-Draft Fixed Bed } \\
\text { Open Core Fixed Bed }\end{array}$ & \multirow{3}{*}{$\begin{array}{l}\text { Any Organic Material } \\
\text { Examples: Agricultural wastes, hazardous organic wastes, } \\
\text { industrial wastes. } \\
\text { Pretreatment: Waste typically segregated. } \\
\text { Qualifications: Dry MSW is favorable. Coal size distribution must } \\
\text { be controlled to ensure good bed permeability. } \\
\text { Final Conversion Technology (Optional): Fischer-Tropsch } \\
\text { Catalytic Conversion }\end{array}$} & \multirow{3}{*}{$\begin{array}{l}\text { Intermediate Products: Combustible gases, liquids, tars, and } \\
\text { inert fluidizing gases. } \\
\text { Final Products: Electricity, Thermal Energy, Hydrogen, Ethanol } \\
\text { and other alcohols, Diesel type fuels, Gasoline. } \\
\text { Co-products: Charcoal, Ash, Carbon Dioxide. }\end{array}$} \\
\hline & & 胥离 & $\begin{array}{l}\text { Pressurized Circulating Fluidized Bed } \\
\text { Atmospheric Circulating Fluidized Bed }\end{array}$ & & \\
\hline & & 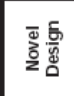 & $\begin{array}{l}\text { Plasma Arc Gasifier } \\
\text { 2-stage Gasifier } \\
\text { Open Top } \\
\text { Aqueous Phase Reforming }\end{array}$ & & \\
\hline & \multirow{2}{*}{ 离 } & 离育 & $\begin{array}{l}\text { Ablative Fast Pyrolysis } \\
\text { Cyclonic Fast Pyrolysis } \\
\text { Rotating Core Fast Pyrolysis } \\
\text { Open Core Fast Pyrolysis } \\
\end{array}$ & $\begin{array}{l}\text { Any Organic Material } \\
\text { Pretreatment: Sorting } \\
\text { Qualifications: None }\end{array}$ & \multirow{2}{*}{$\begin{array}{l}\text { Intermediate products: Syngas and Charcoal } \\
\text { Final Products: Bio-oil and Charcoal } \\
\text { Co-products: Electricity and Thermal Energy }\end{array}$} \\
\hline & & 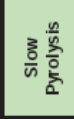 & $\begin{array}{l}\text { Vacuum Pyrolysis } \\
\text { Flash Pyrolysis }\end{array}$ & $\begin{array}{l}\text { Any Organic Material } \\
\text { Pretreatment: Sorting. } \\
\text { Qualifications: Waste must be pre-sorted and processed to } \\
<6 \mathrm{~mm} \text { ( } 1 \text { to } 2 \mathrm{~mm} \text {. preferred) and }<10 \% \text { moisture content to } \\
\text { assure high heat transfer rate. }\end{array}$ & \\
\hline \multirow{7}{*}{ 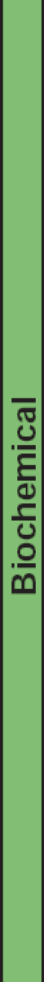 } & \multirow{3}{*}{ 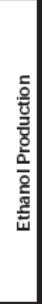 } & \multicolumn{2}{|c|}{ Wet-Mill Fermentation } & $\begin{array}{l}\text { Grains } \\
\text { Mostly: Corn } \\
\text { Pretreatment: Separation of the oil, protein, fiber and the bulk of } \\
\text { the nutrients from the starch }\end{array}$ & $\begin{array}{l}\text { Intermediate Products: Mash, Sugar } \\
\text { Final Products: Ethanol } \\
\text { Co-products: Distillers grains plus solubles, Carbon Dioxide }\end{array}$ \\
\hline & & \multicolumn{2}{|c|}{ Dry-Mill Fermentation } & $\begin{array}{l}\text { Grains, Sugars and Waste, Starches and Sugars } \\
\text { Examples: Grains (corn, sorghum, barley), Sugars (Sugarcane and } \\
\text { beets), Beer, and other waste sugars and starches. } \\
\text { Pretreatment: Grinding, cooking and fermentation }\end{array}$ & $\begin{array}{l}\text { Intermediate Products: Starch, Sugar } \\
\text { Final Products: Ethanol } \\
\text { Co-products: Corn oil, corn gluten meal, corn gluten feed, carbon } \\
\text { dioxide, liquid bio-fertilizers }\end{array}$ \\
\hline & & \multicolumn{2}{|c|}{ Lignocellulosic Biomass Fermentation } & $\begin{array}{l}\text { Cellulosic/Woody Biomass } \\
\text { Pretreatment: Hydrolysis (Dilute Acid, Concentrated Acid, } \\
\text { Enzymatic, Steam explosion) }\end{array}$ & $\begin{array}{l}\text { Intermediate Products: Cellulose, hemicellulose. lignin } \\
\text { Final Products: Ethanol } \\
\text { Co-products: Carbon Dioxide, residual cellulose and lignin, } \\
\text { electricity and thermal energy }\end{array}$ \\
\hline & 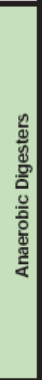 & 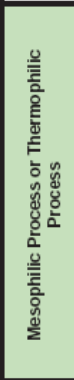 & $\begin{array}{l}\text { Anaerobic activated sludge process } \\
\text { Anaerobic clarigester } \\
\text { Anaerobic contact process } \\
\text { Anaerobic expanded-bed reactor } \\
\text { Anaerobic filter } \\
\text { Anaerobic fluidized bed } \\
\text { Anaerobic lagoon } \\
\text { Anaerobic migrating blanket reactor } \\
\text { Batch system anaerobic digester } \\
\text { Expanded granular sludge bed digestion } \\
\text { Hybrid reactor } \\
\text { Imhoff tank } \\
\text { One-stage anaerobic digester } \\
\text { Submerged media anaerobic reactor } \\
\text { Two-stage anaerobic digester } \\
\text { Upflow anaerobic sludge blanket digestion } \\
\text { Upflow and down-flow anaerobic attached } \\
\text { growth }\end{array}$ & $\begin{array}{l}\text { Almost any organic material: paper, grass clippings, leftover food, } \\
\text { sewages, animal wastes; and other forms of biomass such as } \\
\text { distillers grains. } \\
\text { Pretreatment: Sorting or screening to remove inorganic material. } \\
\text { Qualifications: The material may need to be pre-processed and } \\
\text { water added. }\end{array}$ & $\begin{array}{l}\text { Intermediate products: N/A. } \\
\text { Final Products: Biogas, Thermal Energy, Digestate. } \\
\text { Co-products: Liquid and Solid Biofertilizers. }\end{array}$ \\
\hline & 颉 & \multicolumn{2}{|c|}{ Bioreactor vessel } & $\begin{array}{l}\text { Organic Wastes } \\
\text { Pretreatment: Sorting pre-treatment } \\
\text { Qualifications: The waste must be contained, compacted and } \\
\text { covered in a vessel }\end{array}$ & \multirow{2}{*}{$\begin{array}{l}\text { Intermediate products: Biogas composed of Methane, Carbon } \\
\text { Dioxide, Nitrogen, Hydrogen, Hydrogen Sulfide and Oxygen. } \\
\text { Final Products: Electricity, thermal energy, methane. CNG or LNG } \\
\text { for vehicle fuel. } \\
\text { Co-products: Carbon Dioxide for possible use in greenhouse } \\
\text { operations, and Biofertilizers. }\end{array}$} \\
\hline & 3 & \multicolumn{2}{|c|}{ Landfill Site } & $\begin{array}{l}\text { Organic Wastes } \\
\text { Pretreatment: None Qualifications: None }\end{array}$ & \\
\hline & $\frac{0}{\frac{0}{2}}$ & \multicolumn{2}{|c|}{$\begin{array}{l}\text { Static Pile } \\
\text { Enclosed Compost } \\
\text { Turned Window } \\
\text { In-Vessel Compost } \\
\text { Transesterification }\end{array}$} & $\begin{array}{l}\text { Practically any Organic Waste } \\
\text { Pretreatment: Sorting } \\
\text { Qualifications: A separation between organic and contaminants is } \\
\text { necessary. }\end{array}$ & $\begin{array}{l}\text { Intermediate products: None } \\
\text { Final Products: Valuable Compost } \\
\text { Co-products: Heat and Carbon Dioxide. (May be useful in a } \\
\text { greenhouse environment or for heating) }\end{array}$ \\
\hline $\begin{array}{l}\frac{\bar{J}}{\mathrm{U}} \\
\frac{\mathrm{E}}{\mathrm{D}} \\
\frac{\mathrm{C}}{\mathrm{U}}\end{array}$ & 它 & & & $\begin{array}{l}\text { Oils, fats, used cooking oils, greases, methanol or ethanol and } \\
\text { a catalyst } \\
\text { Pretreatment: Used cooking oils, yellow greases, and some tree } \\
\text { oils are taken through an esterification process to remove fatty acid } \\
\text { that should, preferably, be reduced to less than } 1 \% \text { (at least below } \\
4 \% \text { ). } \\
\text { Qualifications: Essentially any bio-oil, animal fat or tallow, used } \\
\text { cooking oil, yellow/trap grease, plant or tree oil can be corverted } \\
\text { into biodiesel if the fatty acid content is low enough. }\end{array}$ & $\begin{array}{l}\text { Intermediate Products: Oils fats or greases taken through } \\
\text { transesterfication } \\
\text { Final Products: Biodiesel } \\
\text { Co-products: Glycerin, Soaps }\end{array}$ \\
\hline
\end{tabular}




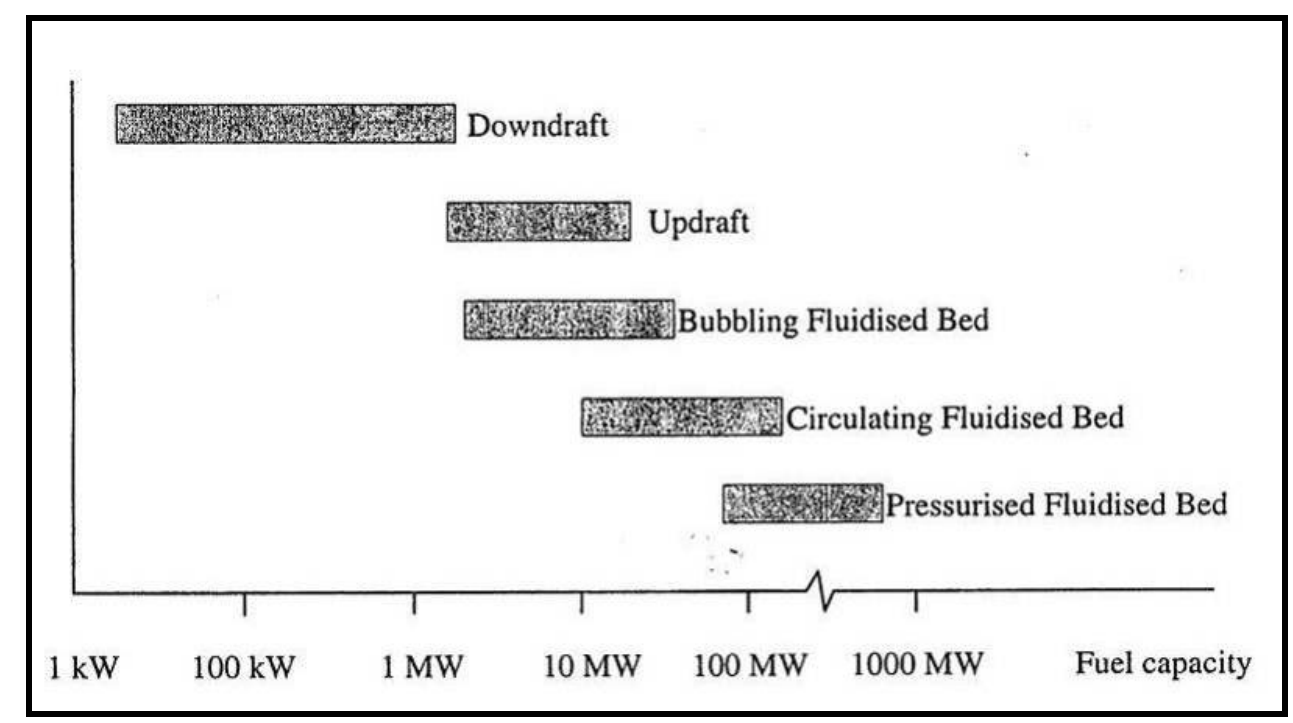

Figure 3. Small-scale gasification.

Key questions to ask when considering a WTE project include:

- What is the composition of the waste?

- Does the waste contain hazardous materials?

- What is the average moisture content of the waste?

- What is the total amount of combustible material available on a daily or annual basis? What percentage of the waste is glass or metal? What processes are in place to pre-process and pre-sort the waste?

- What are the facility and utility requirements? Does the system need water, diesel, external generators, and power conditioning units or any other considerations that will require more space, personnel or resources? Will the system by-products need additional disposal or treatment?

- What energy need are you trying to solve? Heat, power, combined heat and power or liquid fuels?

- Will the unit need to be mobile, or will it be stationary?

- What maintenance and service will the system require and how often will it need to be done? Are spare parts easily accessible?

\subsection{Waste composition-installations}

According to an analysis conducted by the U.S. Army Engineer Research and Development Center (ERDC) (Brandhorst et al. 1995), Army CONUS municipal solid waste (MSW) is much like the MSW of the rest of the United States (i.e., it contains high percentages of paper, organics, and plastic). MSW per capita production is approximately 1 ton/person/year ( $\sim 5 \mathrm{lb}$ / person/ day) based on a 2005 U.S. Environmental Protection Agency (USEPA) Study of Municipal Solid Waste in the United States (USEPA 2008). 
A 2007 U.S. Army Center for Health Promotion and Preventative Medicine (CHPPM) solid waste characterization study (Schafstall 2008) for Aberdeen Proving Ground (APG) found that the majority of the waste consisted of paper, construction and demolition (C\&D), organics, and plastics (Figure 4). During this study, however, it was discovered that the waste composition varied depending on the MSW collection location, e.g., dining facility, range, recreation center, etc.

Figure 5 (derived from data obtained from the Solid Waste Annual Report System [SWARS] Database) shows the composition of waste for Installation Management Agency/ Major Army Command (IMA/ MACOM) installations in the 50 United States for FY2007. The majority of waste is composed of C\&D waste, followed by MSW.

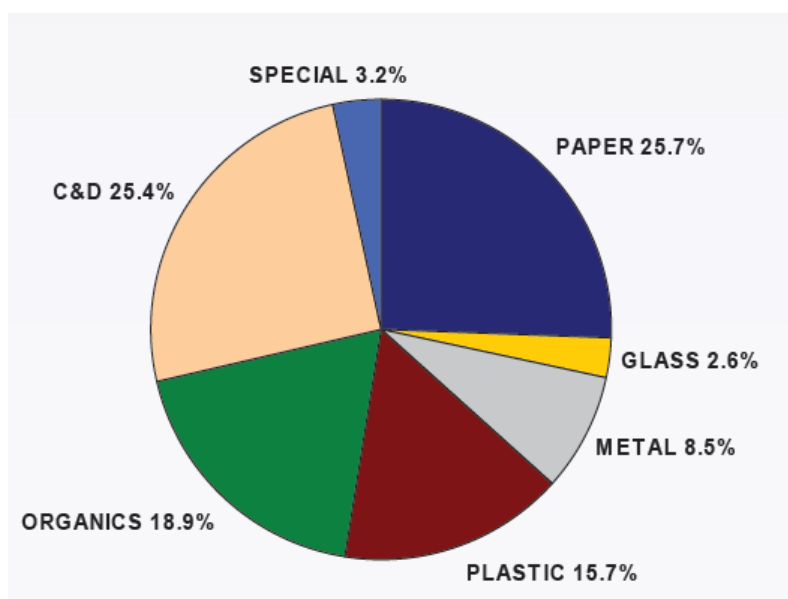

Figure 4. Waste composition-installation APG.

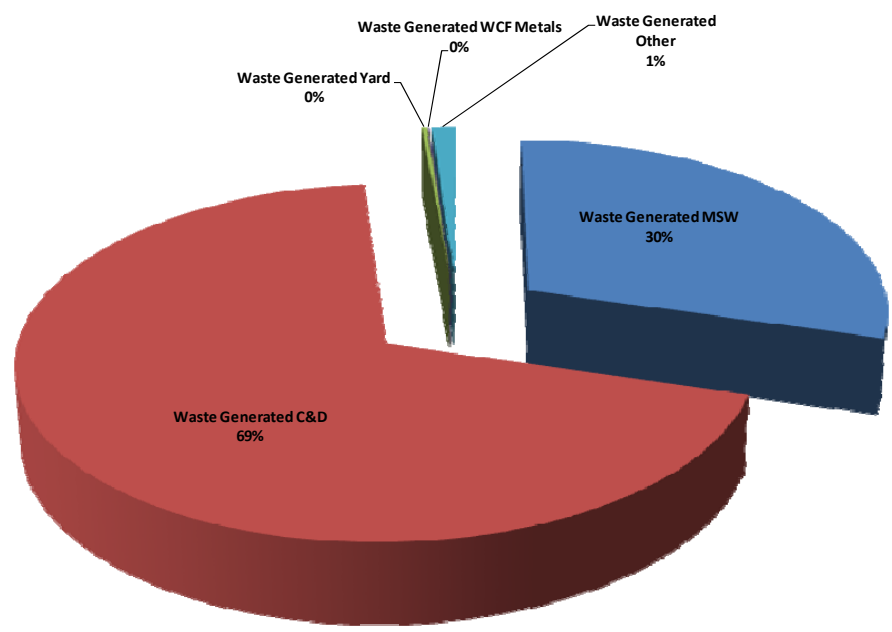

Figure 5. Solid waste generated by the Army IMA/MACOMs in the 50 United States, FY2007. 
During the workshop, it became evident that waste composition differs between installations based on the installation type (e.g., combat training areas, forts, ranges, medical centers, etc.) and the installation's mission. For example, a waste characterization study done at Fort J ackson* determined that the installation's largest waste stream was mattresses and food waste because of Fort J ackson's basic training mission (constant rotations of soldiers processing in and out).

\subsection{Waste composition-deployable}

According to the Natick Soldier Center (Ruppert et al. 2004), base camp (deployable) waste tends to have a greater percentage of packaging waste and food ( 75 to 90 percent) than installation waste. Table 2 lists waste composition from various military installations.

Again, the data show that paper and cardboard, plastic, and food are the most prevalent components. The presence of food within the waste stream is important because of its effect on the overall moisture content of the waste.

\subsection{Fixed installation versus deployable WTE systems}

Also discussed during the workshop was the contrast between fixed installation and deployable WTE systems. It was clear that installations have different drivers to pursue WTE technologies than deployable operations.

For instance, CONUS installations must meet Federal energy and environmental policy goals/requirements and are faced with the costs associated with waste disposal, rising energy costs, and energy security issues. Installations are concerned with both the operational energy economics and the initial capital costs associated with existing technologies. Currently, the costs associated with a WTE program or system would need to be financed by a third party entity that is willing to assume the risk of either building a facility or converting an existing facility to fulfill the necessary requirements.

* ${ }_{\text {http://proceedings.ndia.org/JSEM2006/Thursday/Wuichet.pdf }}$ 
Table 2. Waste composition at selected installations.

\begin{tabular}{|c|c|c|c|c|c|}
\hline & $\begin{array}{l}\text { Army Field } \\
\text { Feeding } \\
\text { System } \\
\text { (Fort Campbell, } \\
\text { April 1995) }\end{array}$ & $\begin{array}{c}\text { Force Provider } \\
\text { Training } \\
\text { Module } \\
\text { (Fort Polk, } \\
\text { June 2000) }\end{array}$ & $\begin{array}{l}\text { AF Bare Base* } \\
\text { (Derived from } \\
\text { PSAB data) }\end{array}$ & $\begin{array}{l}\text { ASG Eagle } \\
\text { Base Camp } \\
\text { (excluding wood) }\end{array}$ & $\begin{array}{l}\text { ASG Eagle } \\
\text { Base Camp } \\
\text { (including wood) }\end{array}$ \\
\hline $\begin{array}{l}\text { Study } \\
\text { Population }\end{array}$ & 210 & 164 & 1182 & 3700 & 3700 \\
\hline $\begin{array}{r}\text { Paper \& } \\
\text { Cardboard }\end{array}$ & $\mathbf{4 5} \%$ & $38 \%$ & $53 \%$ & $49 \%$ & $12 \%$ \\
\hline Plastic & $8 \%$ & $12 \%$ & $26 \%$ & $34 \%$ & $8 \%$ \\
\hline Food & $14 \%$ & $40 \%$ & $2 \%$ & $4 \%$ & $1 \%$ \\
\hline Misc & $12 \%$ & $7 \%$ & $10 \%$ & $8 \%$ & $2 \%$ \\
\hline Metal \& Glass & $21 \%$ & $3 \%$ & $6 \%$ & $5 \%$ & $1 \%$ \\
\hline Wood & - & - & $3 \%$ & - & $76 \%$ \\
\hline $\begin{array}{l}\text { Per Capita } \\
\text { (lbs/person/day) }\end{array}$ & 3.2 & 4.1 & 13.2 & 3.0 & 12.6 \\
\hline Fuel Potential & $79 \%$ & $97 \%$ & $94 \%$ & $95 \%$ & $99 \%$ \\
\hline
\end{tabular}

Outside agencies can also provide support and maintenance to the units so that there are no additional installation personnel required to perform preventative maintenance and service the units.

In contrast, deployable operations are focused more on energy security than on cost or environmental considerations. In deployable operations, there are significant dangers associated with the delivery of fuel to the battlefield or the transport of waste to a landfill or burn site. A major advantage of WTE programs for forward units is the elimination of the need to transport waste for disposal. The benefits of a WTE program are the disposal of waste on site and provision of secure energy for the base.

The space required by the facilities must also be considered. Land will need to be set aside for the collection, sorting, and converting the waste into usable energy. Installations will generally be able to provide more usable land area for these capabilities than deployable units, which can be limited by the footprint that is left behind on foreign territory and by the space taken on a forward base during times of possible conflict. Deployable units can also be viewed as temporary fixtures that may need to be either moved or completely dismantled when forward bases are decommissioned or turned over to the host nation. The high cost of WTE units will greatly reduce their cost effectiveness; packaged systems must be studied to see how the temporary status of the facilities will affect the reliability of WTE units.

Under Executive Order 13423, installations must increase the diversion of solid waste and maintain cost effective waste prevention and recycling 
programs in facilities. This requirement must be taken in the context of the energy efficiency and renewable energy goals within the Executive Order and Energy Policy Act. The workshop attendees discussed the need to balance the two requirements (waste diversion and renewable energy production), and concluded that there is a need for energy and environmental staffs to work together more closely, and to evaluate potential projects in the context of meeting both goals.

Throughout the Army, $\$ 68 \mathrm{M}$ is spent annually disposing of the various forms of waste through landfills, incineration, composting, and recycling (SWARS Database 2008). Efforts are being made to increase the disposal methods that have payback such as recycling, and to involve local communities in composting materials to be later used on the installation. WTE programs could further decrease this cost by eliminating the need to transport waste off-site to disposal areas, and by providing energy for the installation.

\subsection{Project financing and potential funding options}

For energy projects in particular, Army and DoD fixed installations are becoming increasingly reliant on third party financing through contractual mechanisms such as Energy Savings Performance Contracts (ESPCs), Enhanced Use Leases (EULs), or Power Purchase Agreements (PPAs). Demonstration funding is available in limited amounts through the DoD Energy Conservation Investment Program (ECIP), DoD Environmental Security Technology Certification Program (ESTCP), the Army's Installation Technology Transition Program (ITTP), and others. While individual projects can be funded or financed on a case-by-case analysis, the broader potential impact of fielding WTE systems or processes Army or DoD wide cannot be projected without detailed baseline data. 


\section{Workshop Presentation Summaries}

The agenda was comprised of a general overview of waste to energy followed by presentations of current WTE projects and a concluding session with a wrap up discussion and next steps. The following topics were addressed throughout the workshop:

1. Installation Waste to Energy: The Need and Opportunity

2. Waste Characterization

3. Waste-to-Energy Technologies

4. Waste-to-Energy Case Studies.

The following section summarize key points from workshop presentations and the comments and questions raised during those presentations.

\section{1 installation waste streams defined/recoverable energy}

Presenter: René Parker, TARDEC (Support Contractor)

- Provided a general overview of various installation and deployable waste streams (biomass, landfill gas, waste water treatment gas, nonhazardous municipal solid waste, construction and demolition waste and further defined what is meant by energy, i.e., electrical and/ or thermal.

\section{Comments/Questions:}

- Look to third party financing and state incentives; North Carolina University maintains database of state incentives, accessible through URL: http://www.dsireusa.org/.

- Possibility of mining landfills for waste to use for energy, comment that the Under Secretary of the Air Force has said that all landfills will be mined in 50 years.

\subsection{WTE technologies and commercialization status}

\section{Presenter: Mike Warwick, PNNL}

- Current renewable focus on "electricity."

- Energy Independence and Security Act of 2007 has a goal to reduce new building energy from fossil resources to zero by 2030.

- Noted that even the largest Army bases have less than $1 / 10^{\text {th }}$ of the onsite waste feedstock needed to justify capital investment for a real 
'power producing' WTE plant. He also observed that there are few Army bases with nearby municipal waste feedstock needed to justify a collaborative regional waste energy plant.

- Discussed different WTE technologies, including combustion, gasification and plasma.

- Discussed scale issues; minimum size for combustion 20MW ( $\sim 600$ tons/ day), gasification 30-40 MW ( $\sim 900-1200$ tons/ day) and Plasma $6 \mathrm{MW}$ ( $\sim 240$ tons/ day). Large base has about 50 tons/ day of waste.

- Waste to energy is a valid renewable option if:

o there is a significant volume of waste,

o the base faces high tipping fees,

o the base has available land adjacent to the base to site a WTE facility,

o the base and adjacent community can tolerate truck traffic, and

0 an industrial process on-site and the base is able to purchase power from a third party legally (a deregulated electrical industry state).

- Benefits of renewable power are: 24/ 7 power source on or near the base, predictable power costs, and potential environmental savings.

\section{Path Forward Questions Posed by Mr. Warwick:}

1. What technologies are sufficiently mature, economical, and environmentally benign for on-base use?

2. Are there any advantages of waiting from improved technologies versus grabbing the current fuels using current technologies?

3. What "fuel" resources exist, where do they exist, and do they exist in appropriate quantity and duration to support on-base plants? At which installations are these conditions met?

4. What are the barriers to procurement at the promising sites? Can they be overcome through workarounds or legislation?

5. What mitigation methods may be available for the potential technical, economic, and environmental risks?

6. Is a common market engagement procurement approach better than the current project by project process?

7. Can a single Environmental Impact Statement be developed for the same technology used at multiple sites?

8. Should DoD or the services pursue a single contract for projects at multiple sites? Is it better to have one vendor/ technology, or multiple? 


\section{Comments/Questions:}

- Need to put together a four page white paper on waste to energy that can be briefed to leadership.

\subsection{Demonstration of solid waste reduction systems for Army operations}

\section{Presenter: Mr. Thomas Guinivan, U.S. Army Environmental Command, National Defense Center for Energy and Envi- ronment}

- Stressed the need for landfill diversion to avoid costly refuse 'tipping' fees.

- Army installations landfill large volumes of municipal solid waste; some installations spend $>\$ 1 \mathrm{M}$ annually in tipping fees.

- Solid waste issues have led to the development of a task to identify, validate, and help implement technologies that convert solid waste into essential resources, i.e., energy.

- Technology preferences include the ability to handle various waste streams without sorting, produce at least one usable by-product, modular, scalable, rugged, simple to operate and maintain, minimal facility requirements, and compatible with Army infrastructure.

- Conducted a feasibility study where some 20 vendors were analyzed based on a technical and cost questionnaire.

- Next step is to identify a technology and conduct demonstration and validation testing.

\section{Comments/Questions:}

- Provide copy of WTE technology feasibility study to the group

\subsection{Fort Detrick Enhanced Use Lease (EUL) energy plant}

Presenter: COL Don Archibald, Center for Health Promotion and Preventative Medicine (CHPPM)

- Co-generation utility plant was requirements driven, determined by who needed energy and how badly, and by what was important to the users (reliability and quality).

- Use of Enhanced Use Lease (EUL) 36-year out-lease with 14-year option, design/build took 18 months, \$103 million dollar construction cost.

- Energy services provided through a Federal Acquisition Regulations (FAR) based utility contract for 10 years with two renewable periods. 


\section{Comments/Questions:}

- Project began as a need for "islanding" capability, not a WTE project.

- Example of an Enhanced Use Lease project.

\subsection{Installation waste quantity and characterization}

\section{Presenter: Stephen Cosper, U.S. Army Engineer Research and Development Center}

- Provided a comparison between typical U.S. waste and installation waste and deployable waste both in terms of characterization and amount.

- Provided information on the Solid Waste Annual Reporting System (SWARS) Website as a source for determining the amount of waste generated on installations.

- Found that the amount of waste generated per capita at installations was much like that in the United States overall ( $~ 1$ ton/yr/person), however the deployable waste generated was much greater ( $16 \mathrm{lb} /$ day/ person) and was very heavy on packaging, shipping, and food.

\section{Comments/Questions:}

- Fort J ackson's biggest waste stream is mattresses and food waste because of its basic training mission.

- Seems that the waste stream is driven by the mission of the installation.

\subsection{WTE at Aberdeen Proving Ground}

\section{Presenter: Daniela Caughron, Aberdeen Proving Ground}

- Provided an overview of the current WTE plant and steam project and also laid out plans for an expansion to include electricity production from the WTE plant.

- Steam is very important to APG; need heat, warm water, and process steam to operate buildings and perform their mission.

- Annual steam consumption is 759,000 Mlbs and is expected to rise to 972,000 Mlbs in the near future.

- Existing WTE plant (controlled air incineration) commenced operation in J anuary 1998 and has a capacity of 360 tons/ day of municipal solid waste (approximately 400 tons/ year of scrap metal removed from ash floor). 
- Expansion underway to increase the plant to 1600TPD provide all steam and some electricity to the installation.

\section{Comments/Questions:}

- WTE plant is located outside of the installation and the installation buys the steam from the plant.

- Working with an Energy Service Performance Contractor to identify financing for an expansion that would include electrical production.

- Appears to be a gap between R\&D funding and O\&M funding.

\subsection{Eielson Air Force Base rotary kiln gasifier design}

\section{Presenter: Tom Davison, Air Force Advanced Power Tech- nology Office}

- Provided overview of current project called "Alaskan Energy from Waste" (AEW), which is a congressionally funded demonstration of a rotary kiln gasifier technology.

- Currently researching site location and waste stream, Phase II will include the procurement of materials and equipment, build and start-up, and Phase III will turn the equipment over to the host site for ownership and operation.

- Lessons learned are that location, funding, and communication are key.

\subsection{Super Critical Water Oxidation (SCWO) WTE technology}

\section{Presenter: Stan Rising, Air Force Research Laboratory}

- Develop, build, and demonstrate a compact super critical water oxidation reactor prototype to dispose of military generated waste materials while recovering energy and other usable materials.

\section{Comments/Questions:}

- Comments about energy and environment communities coming together.

- The Achilles Heel is permitting of WTE facilities. 


\subsection{Food and packaging WTE technology}

\section{Presenter: Mr. Don Pickard, U.S. Army Natick Soldier RD\&E Center (NSRDEC)}

- Focused on waste to energy for deployed bases. He stated his office focus is to ... "Develop and demonstrate technologies that treat solid waste as a resource, producing useful energy while minimizing field waste." He spoke of the need for deployed base WTE technology that becomes a means to not only power the waste process itself, but also to provide some modicum of power for the deployed base as well.

- Capability provided is the conversion of solid waste into electricity and high quality heat while reducing logistics tail of fuel consumed and trash back-hauled.

- Focus of the research is on finding solutions that fit within the Force Provider requirements; use 60kW tactical quiet generators for kitchen, dining, and sanitation.

- Force Provider is the Army's all-inclusive base camp (climatecontrolled billeting, quality food, and dining facilities, hygiene services, and MWR faculties): supports 550 personnel, power consists of 24 $60 \mathrm{~kW}$ TQGs, consumes $2248 \mathrm{gal}$ of fuel per day and produces $2000 \mathrm{lb}$ of waste per day.

- Paradigm shift of today, which looks at waste as a liability and tomorrow which looks at waste as energy.

- Thermo-chemical WTE concept consists of three major components: (1) pre-processing, (2) conversion, (3) power generation.

- Investigating both downdraft gasifiers and supercritical water depolymerization. The gasifier technology is relatively mature and has been successfully demonstrated (TRL-6). The plan is to transition to PM Force Sustainment Systems for the Systems Development and Demonstration Phase in FY10.

\section{Comments/Questions:}

- No current ATO for waste to energy (although ASA(ALT) cancelled an approved ATO in FY06), work done through SBIRs and DARPA funding (MISER), unsuccessful in obtaining funding through the Strategic Environmental Research and Development Program (SERDP) or Environmental Security Technology Certification Program (ESTCP).

- NSRDEC works within the 6.2/6.3 realm and transitions technology to Product Manager Force Sustainment Systems (PM FSS) responsible for System Development and Demonstration (6.4/ 6.5). PM FSS is collocated at Natick with S\&T and Logistics (TACOM's Integrated Logistics 
Support Center) and has a Total Life Cycle Management Plan for introducing new technology to the field like the Waste to Energy Converter (WEC).

- The Natick concept of parking a relatively small WEC adjacent to the kitchen so that the waste stream is controlled (no hazardous waste) and is readily processed into energy (100kW) that powers the kitchen and other Force Provider subsystems is a departure from municipal operations and virtually all other plans for WEC, which depend on trucking waste from a broad geographic area to a large central processing station $(+1 \mathrm{~mW})$. By scaling down and removing the trucks, the Natick overall energy balance appears to be far more positive and less material and labor intensive than other concepts.

\subsection{CoNsolidated and Deployable Omni-Recycling (CONDOR)}

\section{Presenter: Seth Foulkes, Air Force Research Laboratory (Support Contractor)}

- Current WTE project to manage liquid and solid waste to maintain sanitary conditions at deployed facilities.

- Hydrothermal concept includes the microbial hydrogen production by dark fermentation of liquid wastes; produces clean water, electricity (via hydrogen fuel cells), and ash.

- Potential savings of $\$ 18,000$ / day or $\$ 6.5 \mathrm{M}$ per year ( $\$ 3 \mathrm{M}$ capital investment).

- Current cost per day to manage current waste is $\$ 13,000$.

- Wrapping up R\&D efforts, next step is to demonstrate and validate.

\subsection{Tactical Garbage to Energy Refinery (TGER)}

\section{Presenter: Power Surety Task Force (Note: Presenter: Power Surety did not send a representative to the workshop to present)}

- History of the project is that it was a research project at Purdue University, funding ended and RDECOM asked the Rapid Equipping Force to fund the project.

- Deployed TGER in May-August 2008 for a 90-day user assessment/ feedback. 


\subsection{Military encampment waste to electrical power system/wrap-up}

\section{Presenter: Harold Sanborn, TARDEC}

- Briefly discussed TARDEC's current WTE project called the Mobile Encampment Waste to Electrical Power System (MEWEPS), which uses a downdraft gasifier technology to gasify solid waste and use resulting producer gas in a 60kW Tactical Quiet Generator to produce electricity.

- Discussed the importance of sharing information among services and within the same services to better understand technology readiness of the WTE technologies. Recognized the inherent linkage between the environmental and energy communities and stressed the need to better understand the opportunities and barriers of implementing WTE projects both on installations and in the field.

\section{Comments/Questions:}

- IMCOM funded PNNL to look at renewable energy technologies, waste to energy is not seen as favorably as other renewable resources.

- How do we quantify the environmental aspect?

- What is the mix of recycled material versus landfill amounts and costs? Example provided of Fort Bragg that ships its waste 77 miles to a landfill.

- Need to connect waste to energy with energy security and look at the application of waste to energy in contingency operations.

\subsection{Where do we go from here? Opportunities, technology gaps, formalizing relationships, wrap-up and action items}

\section{Presenter: Frank Holcomb, CERL}

- Re-capped the presentations and discussions over the 2-day workshop and then opened the discussion among the group.

- Topics of discussion included:

o mining landfills

o the elimination of waste at installations and how this effects WTE projects

o portable technologies that can be used for training on installations and then deployed

o opportunities to use vast government land to grow energy crops or site WTE facilities (Enhanced Use Lease opportunities)

o the need to better understand the amount of waste available and what the true "burdened cost" of the waste is (landfill tipping fees, transportation to move the waste, etc.). 


\section{Key Points from Group Discussion}

At the end of the 2-day workshop, the group entered into a facilitated discussion. Key points generated from that discussion follow.

\subsection{General}

- A need exists to determine the "burdened" cost of waste remediation.

- A need exists to better communicate WTE potential with a business case that addresses energy, environmental and cost implications.

- A need exists to better coordinate between environmental and energy entities at the installation on waste to energy.

- A need exists to identify the "sweet spot" for technology objectives that reduce waste while identifying energy opportunities.

- A need exists to develop a matrix of WTE data (waste stream/ technology/ scale).

- A need exists to develop a notional roadmap for waste to energy.

- A need exists to determine requirements for both installations and field by matching WTE technologies with the mission.

- A need exists to approach U.S. Army Training and Doctrine Command (TRADOC) and Installation side for requirements.

- A need exists to share ideas and lessons learned with others both in and out of your organization.

- A need exists to develop a WTE center of excellence that would include technical, subject matter experts, legal, environmental, regulatory, contracting, and financial resources to assist installations in the planning and implementation of WTE projects.

- The question of how the requirement to minimize or eliminate solid waste on installations fits with concept of using waste to produce energy needs to be explored and/ or resolved.

- Different drivers exist for installations (environmental impacts and energy requirements) than for those in the field who may only be focused on energy and reducing the logistics tail.

- The idea that training bases may be used to test and evaluate technologies for future deployment should be explored.

- Waste to energy should be connected with the mission at the installation, and ultimately with the warfighter.

- It is important to identify common missions with installations e.g., National Guard, training, depots, etc. 
- The use of Mobile WTE units for contingency operations should be investigated.

- A need exists to review exactly who the stakeholders are to make sure that all are invited to participate.

- West Point offers an opportunity for cadets to learn about energy, specifically waste to energy. It may be possible to use this resource to explore the true burdened cost of waste.

- There is a need to determine how waste to energy may be tied into the Leadership for Energy and Environmental Design (LEED).

- The WTE topic should be presented at the GovEnergy conference.

- One of the workshop participants a proposed path forward by phase.

\subsection{Short Term}

- Identify policy impedances and enablers.

- Disseminate lessons learned from on-going projects.

- Create government/private partnerships and incentives.

- Define user requirement priorities by waste type and installation function.

\subsection{Intermediate}

- Differentiate technologies by major objectives.

- Develop OCONUS technology candidates.

- Demonstrate CONUS technology candidates.

\subsection{Long Term}

- Merge policy options to foster technology transfer.

- Develop technology drivers with regard to an established requirements process.

- Establish a smooth flow of energy/ power generation; interconnect to grid and/ or distributed generation.

- Allow innovative funding mechanisms to enable mixed funding sources based on previously tried solutions. 


\section{Conclusions and Next Steps}

\subsection{Summary}

The 1st Army Installation Waste to Energy Workshop was held at the Army Research Office (ARO) in Research Triangle Park, NC over a 2-day period in which subject matter experts and government stakeholders with current WTE projects gave presentations, shared information, and participated in discussion groups to explore the potential for application of WTE technologies at Army (and Department of Defense) installations, and to potentially launch working groups to further advance the implementation of installation WTE technologies.

The discussions during the workshop provided more questions than answers with regards to the potential for implementation of WTE conversion technologies at Army and DoD fixed installations. Waste processing itself is a very important goal for the environmental community that may or may not result in "excess" energy delivery for other purposes. The waste types and amounts, as well as the process(es) employed for conversion will determine the amount of viable energy that can be delivered.

Many energy and environmental goals and requirements appear to support the implementation of WTE technologies. However, no baseline data are available for even a high level analysis of the opportunities for these technologies at installations based on installation size, mission, location, or other metrics. In addition, energy and environmental managers at installations may not identify or assess waste conversion opportunities (whether economic, energy, environmental, or some combination thereof) using the same metrics or selection criteria. Finally, some WTE projects are being implemented at installations, but on a single project basis and only through innovative partnerships or Congressionally-funded demonstrations. It may be more economical (but with increased complexity and risk) for fixed installations to partner with surrounding civilian communities, than to go it alone with much smaller waste streams inside the fence.

\subsection{Recommendations and next steps}

\subsubsection{Study of the "burdened" cost of waste}

A study to estimate the "burdened" cost of waste for particular waste streams across the Army and DoD would be beneficial to assess the poten- 
tial impact of WTE systems. LTC Mark Smith of USMA West Point suggested this would be a good cadet Capstone project, if another agency were willing to provide sponsorship and funding.

\subsubsection{Waste conversion screening tool/application database}

A simple waste conversion screening tool/application database would be helpful to provide information on WTE technologies. This database could include additional information to give installations interim guidance on available contracting mechanisms. Technology information should include topics such as feedstock, conversion process, operational and maintenance requirements, mobility, capital costs, end-use products, and potential economic, energy, and environmental impacts.

\subsubsection{Central repository for WTE information}

To reduce duplication and promote leveraging among the Services, a knowledge database of planned or implemented WTE projects or efforts should be developed. ERDC-CERL offered a web page for the collection of such information through URL: http://dodfuelcell.cecer.army.mil/rd/Waste-to-Energy.php.

\subsection{4 $2^{\text {nd }}$ Installation Waste to Energy Workshop}

It is recommended that a $2^{\text {nd }}$ installation waste-to-energy workshop be held. This workshop should include additional case studies of successful implementations of WTE projects at fixed installations, with a discussion of the various financing mechanisms that were used. Invitations should be made to both installation energy and environmental managers to ensure that their respective perspectives are voiced and understood. 


\section{References}

2007 Federal Energy Management Program (FEMP) Renewable Energy Requirement Guidance for EPACT 2005 and Executive Order 13423 Final, 28 J anuary 2008. Prepared by the U.S. Department of Energy, Office of Energy Efficiency and Renewable Energy Federal Energy Management Program. Accessed 05 May 2008, http://www1.eere.energy.gov/femp/pdfs/epact05_fedrenewenergyguid.pdf

Army Energy Campaign. 2005, http://army-energy.hqda.pentagon.mil/programs/plan.asp

Bain, Amos, Downing, Perlack 2003. Highlights of biopower technical assessment: state of the technology and industry. Technical Report NREL/ TP-510-33502. April National Renewable Energy Laboratory. Accessed 05 May 2008, http://www.nrel.gov/docs/fy03osti/33502.pdf

Bain, R. 2000. Small modular biopower initiative phase I: Feasibility studies executive summaries. Technical Report NREL/ TP-570-27592. National Renewable Energy Laboratory. Accessed 05 May 2008, http://www.nrel.gov/docs/fy00osti/27592.pdf

Baker, G., Integrated battlefield support system: project report. 2007. QinetiQ/ EMEA/TS/ TWP0706269/1.0.

Brandhorst, J . L., and Snyder, M. E. 1995. Army materiel command solid waste survey and analysis. Technical Report EP-95/06. Champaign, IL: U.S. Army Construction Engineering Research Laboratory.

Concurrent Technologies Corporation (CTC). 2007. Solid waste reduction systems, final feasibility study: Phase I. Contract No. W74V8H-04-D-0005, Task No. 0458, CDRL No. A004. Government Access only.

Concurrent Technologies Corporation (CTC). 2008. Solid waste reduction systems, final feasibility study: Phase II. Contract No. W74V8H-04-D-0005, Task No. 0458, CDRL No. A007. Government Access only.

Department of Defense Key Directives. 2008, http://army-energy.hqda.pentagon.mil/policies/key_directives.asp

Energy Independence and Security Act of 2007 (EISA). 2007. U.S. Government Printing Office. Accessed 01 August 2008, http://frwebgate.access.gpo.gov/cgibin/getdoc.cgi?dbname=110_cong_bills\&docid=f:h6enr.txt.pdf

Executive Order 13423-Strengthening Federal Environmental, Energy, and Transportation Management. 2007. Office of the Federal Environmental Executive, Federal Register. Accessed 05 May 2008, http://ofee.gov/eo/E0_13423.pdf, http://ofee.gov/eo/e013423_main.asp

FY2007 Army Environmental Requirements and Technology Assessments (AERTA). 2007. Prepared for the Office of the Director, Environmental Programs (ODEP), by the U.S. Army Environmental Command (USAEC) 
General Atomics. 2006. Mobile integrated sustainable energy recovery (MISER) program - supercritical water depolymerization. Contract No. W911QY-04-C-0077, government access only.

Gerdes, G. L. 2008. Solid Waste Generation Rates at Army Base Camps. Public Works Technical Bulletin 200-1-51. Headquarters, U.S. Army Corps of Engineers (HQUSACE), http://www.wbdg.org/ccb/ARMYCOE/PWTB/pwtb_200_1_51.pdf

Gerdes, G. L., and J antzer, A. L. 2006. Base camp solid waste characterization study. ERDC-CERL TR-06-24. Champaign, IL: U.S. Army Construction Engineering Research Laboratory.

Hathaway, S. A., and Dealy, R. J . 1977. Technology evaluation of Army-scale waste to energy systems. Technical Report No. E-110/ADA042578. Champaign, IL: U.S. Army Construction Engineering Research Laboratory.

Larson, Eric D. 1998. Small-scale gasification-based biomass power generation. Prepared for the Biomass Workshop, Changchun, J ilin Province China 12-13 J anuary 1998, http://www.princeton.edu/ energy/publications/pdf/1998/Small_scale_\%20gasification.pdf

LMOP-EPA Landfill Database, http://www.epa.gov/methanetomarkets/

Logistics Management Institute. 2004. An analysis of the energy potential of waste in the field. DRP30T1. Accessed 05 May 2008, http://www.combatfeeding.org/sbir2005/files/a05-037/DRP30T1.pdf

Niessen, Marks, Sommerland, Camp Dresser \& McKee. 1996. Evaluation of gasification and novel thermal processes for the treatment of municipal solid waste. REL/TP430-21612. National Renewable Energy Laboratory. Accessed 02 May 2008, http://www.osti.gov/bridge/servlets/purl/10164285-7CBnFx/webviewable/10164285.PDF

Perez, G., Neathammer, R., Holcomb, F., Ducey, R., Kim, B., and Louis, F. 2006. Wasteto-energy ECIP (Energy Conservation Investment Program) project, Volume I: An analysis of hydrogen infrastructure fuel cell technology. ERDC-CERL TR-067. Champaign, IL: U.S. Army Construction Engineering Research Laboratory.

RenoSam and Rambøll. 2006. The most efficient waste management system in Europe Waste-to-energy in Denmark. www.federambiente.it/moduli/Workshop\%20Federambiente-ENEA/WastetoEneryinEurope.pdf

Rensfelt, Erik, and Ostman, Anders. Sub-task 6-gasification of waste summary and conclusions of twenty-five years of development, IEA biomass agreement, Accessed 02 May 2008, http://media.godashboard.com/gti/IEA/WastelEA25years.pdf

Ruppert, Bush, Verdonik, Geiman, and Harrison, Hughes Associates, Inc. 2004. Force provider solid waste characterization study. (NATICK/TR-04/ 017). Baltimore, MD. Accessed 05 May 2008, http://stinet.dtic.mil/cgibin/GetTRDoc?AD=ADA427565\&Location=U2\&doc=GetTRDoc.pdf

Sawyer, M. 2008. Electricity Generation using the transportable waste-to-energy system (TWES) (Executive Summary). Air Force Research Laboratory (AFRL/MLQF), Rev. 04.2.

Sawyer, Mikel. 2008. Electricity generation using the transportable waste to energy system (TWES). Air Force Research Laboratory. 
Schafstall, Tim, "Solid Waste Characterization at an Army Facility” Location: Aberdeen Proving Ground, MD, U.S. Army Center for Health Promotion and Preventative Medicine, Ground Water and Solid Waste Program. Accessed 05 May 2008, http://proceedings.ndia.org/isem2007/3813_Schafstall.pdf

Timpe, Mann, Schmidt, Energy \& Environmental Research Center-University of North Dakota. 2000. Gasification for distributed generation-Task 3.5 final topical report, May 1, 1999-March 31, 2000. UND EERC-DOE. National Energy Technology Laboratory. Accessed 02 May 2008, http://www.osti.gov/bridge/servlets/purl/824977-CdHCRS/native/824977.pdf

U.S. Army Solid Waste Annual Reporting System (SWARS) Database. https://aero.apgea.army.mil//

U.S. Department of Energy, National Renewable Energy Laboratory. 2000. A biopower triumph - the gasification story, http://www.nrel.gov/docs/fy00osti/28330.pdf

U.S. Department of Energy. 2008. Biomass Multi-Year Program Plan March 2008, Office of the Biomass Program, Energy Efficiency and Renewable Energy, http://www1.eere.energy.gov/biomass/pdfs/biomass_program_mypp.pdf

U.S. Department of Energy. 2008. Federal energy management program, energy policy act 2005. Accessed 05 May 2008, http://www1.eere.energy.gov/femp/about/legislation_epact_05.html

U.S. Environmental Protection Agency (USEPA). 2008. Solid waste combustion/ incineration. Accessed 02 May 2008, http://www.epa.gov/epaoswer/non$\underline{\mathrm{hw} / \mathrm{muncpl} / \text { landfill/sw_combst.htm }}$

URS Corporation. 2005. Conversion technology evaluation report, appendices. Prepared for City of Los Angeles. Accessed 02 May 2008, http://www.ladpw.com/epd/tf/Attachments/SubCommittee\%20Attachments/CT_Eval_Rpt_Ap p.pdf\#search=\%22gasifying\%20tires\%20lime $\% 22$

URS Corporation. 2005. Summary report: evaluation of alternative solid waste processing technologies. Prepared for City of Los Angeles, http://www.lacity.org/SAN/alternative-technologies-summary-report.pdf

Wolk, R., Lux, S., Gelber, S., and Holcomb, F. 2007. Direct carbon fuel cells: Converting waste to electricity. ERDC-CERL TR-07-32. Champaign, IL: U.S. Army Construction Engineering Research Laboratory. 


\section{Appendix A: Waste-to-Energy Workshop Background Document}

Workshop Purpose: To inform government officials of the potential of $D o D$ waste to energy systems and to launch working groups that will advance the growth of the field.

30,000 Foot Level View:

$>$ Waste to Energy: The Need and Opportunity

$>$ Waste Characterization

$>$ Waste to Energy Technologies

$>$ Waste to Energy Case Studies

\section{Introduction}

This document is intended to help prepare invitees to the Waste to Energy (WTE) Workshop for participation in a waste-to-energy discussion. In preparing for the workshop, it is necessary to first define what is meant by "waste to energy" and to narrow the focus of what will be discussed during the 2-day workshop. Waste-to-energy definitions, requirements for the production and use of "renewable energy" on Federal installations, waste characterization/ availability and waste conversion technologies will be addressed. This document is only a starting point from which to initiate discussion. It is anticipated that this workshop will be the first of many for government stakeholders to share information and to develop a targeted approach to pursue waste-to-energy opportunities both on installations and at deployed (forward operating) locations.

\section{Waste Defined}

What is meant when the term "waste to energy" is used? The term has many different meanings to different people. Typically, waste is defined as garbage/ refuse, something that no longer has use or value. For the purposes of this document and the workshop, the term "waste to energy" will be defined within the context of U.S. Federal energy and environmental policy. As such, the definitions below may challenge the typical definition of "waste" and define it in such a way that "waste" may in fact begin to have "use" or "value" when considered from an energy recovery perspective. 
The Energy Policy Act of 2005 (EPACT 2005) and Executive Order 13423 (E.O. 13423) both identify "biomass, landfill gas, and/ or municipal solid waste" as renewable energy sources.

However, the term "energy" is defined differently between the two documents. Within EPACT 2005 "renewable energy" is limited to "electrical" energy, whereas, in E.O. 13423, "renewable energy" includes both electrical and thermal.

\section{Definitions}

\section{EPACT 2005}

Renewable Energy - electric energy generated from solar, wind, biomass, landfill gas, ocean (including tidal, wave, current, and thermal), geothermal, municipal solid waste, or new hydroelectric generation capacity achieved from increased efficiency or additions of new capacity at an existing hydroelectric project.

Biomass - Any lignin waste material that is segregated from other waste materials and is determined to be nonhazardous by the Administrator of the Environmental Protection Agency and any solid, nonhazardous, cellulosic material that is derived from:

(A) any of the following forest-related resources: mill residues, precommercial thinnings, slash, and brush, or nonmerchantable material;

(B) solid wood waste materials, including waste pallets, crates, dunnage, manufacturing and construction wood wastes (other than pressure-treated, chemically-treated, or painted wood wastes), and landscape or right-of-way tree trimmings, but not including municipal solid waste (garbage), gas derived from the biodegradation of solid waste, or paper that is commonly recycled;

(C) agriculture wastes, including orchard tree crops, vineyard, grain, legumes, sugar, and other crop by-products or residues, and livestock waste nutrients; or

(D) a plant that is grown exclusively as a fuel for the production of electricity. 


\section{Executive Order 13423}

Renewable Energy - electric energy from all renewable energy sources that satisfy the definitions and qualifications in EPACT 2005 and qualified non-electric energy from new renewable energy sources of the types detailed in EPACT 2005. Examples include, but are not limited to, thermal energy from solar ventilation pre-heat systems, solar heating and cooling systems, biomass heating, and thermal uses of geothermal and ocean resources.

\section{Energy Information Administration (EIA)}

Renewable Energy - "Energy resources that are naturally replenishing, but flow-limited. They are virtually inexhaustible in duration, but limited in the amount of energy that is available per unit of time. Note that this definition defines renewable energy according to its primary source, which contrasts with other definitions that define any recurring waste stream as renewable." Applying this definition, the EIA has begun to divide municipal solid waste into biogenic versus non-biogenic waste. ${ }^{\dagger}$

Biomass Waste - Defined by the Energy Information Administration as organic non-fossil material of biological origin that is a byproduct or a discarded product. "Biomass waste" includes municipal solid waste from biogenic sources, landfill gas, sludge waste, agricultural crop byproducts, straw, and other biomass solids, liquids, and gases, but excludes wood and wood-derived fuels (including black liquor), biofuels feedstock, biodiesel, and fuel ethanol. Note: EIA "biomass waste" data also include energy crops grown specifically for energy production, which would not normally constitute waste. ${ }^{\ddagger}$

\footnotetext{
* U.S. Department of Energy, Energy Efficiency and Renewable Energy, Federal Energy Management. 28 January 2008.The 2007 Federal Energy Management (FEMP) Renewable Energy Requirement Guidance for EPACT 2005 and Executive Order 13423 Final. 30 April 2008, http://www1.eere.energy.gov/femp/pdfs/epact05_fedrenewenergyguid.pdf 


\section{Department of Energy}

Municipal Solid Waste (MSW)

Waste material from households and businesses in a community that is not regulated as hazardous.

\section{Municipal Waste}

As defined in the Energy Security Act (P.L. 96-294 1980) as "any organic matter, including sewage, sewage sludge, and industrial or commercial waste, and mixtures of such matter and inorganic refuse from any publicly or privately operated municipal waste collection or similar disposal system, or from similar waste flows (other than such flows that constitute agricultural wastes or residues, or wood wastes or residues from wood harvesting activities or production of forest products)."

\section{Municipal Waste-to-energy Project (or Plant)}

A facility that produces fuel or energy from municipal solid waste. *

\section{Requirements}

EPACT 2005

The President, acting through the Secretary of Energy, shall seek to ensure that, to the extent economically feasible and technically practicable, of the total amount of electric energy the Federal government consumes during any fiscal year, the following amounts shall be renewable energy:

- Not less than 3 percent in fiscal years 2007 through 2009

- Not less than 5 percent in fiscal years 2010 through 2012

- Not less than 7.5 percent in fiscal year 2013 and each fiscal year thereafter

\section{E.0. 13423}

Ensure that at least half of the statutorily required renewable energy consumed by the agency in a fiscal year comes from new renewable sources 
and to the extent feasible, the agency implements renewable energy generation projects on agency property for agency use.

Ensure that the agency reduces the quantity of toxic and hazardous chemicals and materials acquired, used, or disposed of by the agency, increases diversion of solid waste as appropriate and maintains cost effective waste prevention and recycling programs in its facilities.

\section{Why Waste to Energy?}

The increased focus on energy is primarily driven by an overarching need to reduce U.S. dependence on fossil fuels; significantly reduce the production of greenhouse gas emissions; and ensure energy security.

In response, the Energy Policy Act of 2005 and Executive Order 13423 directed Federal agencies to reduce energy consumption, reduce petroleum fuels, and to increase the use of clean, alternative fuels and to increase the amount of renewable energy consumed and encourage the on-site production of renewable energy.

Waste to energy, offers an opportunity for Federal agencies to meet their renewable energy goals while also addressing the environmental and economic issues of waste disposal.

The production and use of renewable energy from "waste" is one approach that can assist in attaining Federal energy goals. Renewable Energy, as defined in EPACT 2005 and E.O. 13423 includes energy from biomass, landfill gas and municipal solid waste.

*

U.S. Department of Energy, Energy Efficiency and Renewable Energy, Federal Energy Management. 28 January 2008. 2007 Federal Energy Management (FEMP) Renewable Energy Requirement Guidance for EPACT 2005 and Executive Order 13423 Final. 30 April 2008, 
In addition to energy requirements, Executive Order 13423 also directs Federal agencies to:

- use sustainable environmental practices, including acquisition of bio-based, environmentally preferable, energy efficient, water efficient and recycled content products;

- increase the diversion of solid waste; and

- maintain cost effective waste prevention and recycling programs in facilities.

Waste to energy connects the two requirements (renewable energy production/ consumption and waste diversion) and ensures an opportunity to meet both.

Things to Think About ...

- One million tons of municipal solid waste (MSW) can yield about 300 standard cubic feet per minute (scfm) of recoverable landfill gas (LFG) or about $800 \mathrm{~kW}$.

- A LFG project that uses 300 scfm yields the same reduction in green house gases as removing an estimated 6,000 cars from the road for a year.

Source: BAMF

\section{DoD Waste Resources}

- According to the Fiscal Year 2007 Defense Environmental Program Annual Report to Congress, DoD generated 5.8 million tons of solid waste (3.4 million tons of Construction and Demolition debris and 2.5 million tons of nonhazardous municipal solid waste). DoD's overall FY2007 diversion rate was 60 percent ( 73 percent C\&D debris diversion rate and 40 percent diversion rate for nonhazardous municipal solid waste).

- An assessment of biomass resources on or near Federal installations by the Department of Energy, Biomass, and Alternative Methane Fuels found that there are:

o nearly 4700 raw wood processors within a 50-mile radius of 1800 large Federal facilities;

o nearly 1200 Federal facilities within 15 miles of a landfill and 500 landfills without an active biogas project; and

o 850 large wastewater treatment plants located within 15 miles of almost 1,400 Federal facilities (Figure A1). ${ }^{\dagger}$

* Office of the Deputy Under Secretary of Defense Installations and Environment. Defense Environmental Programs Annual Report to Congress Fiscal Year 2007. 30 April 2008, https://www.denix.osd.mil/portal/page/portal/denix/environment/ARC

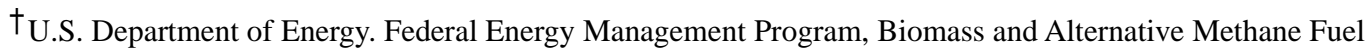
(BAMF) Resources Fact Sheet 30 April 30 2008. http://www1.eere.energy.gov/femp/pdfs/bamf_resources.pdf 


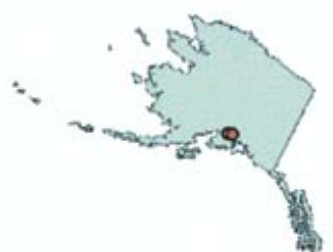

\section{Legend}

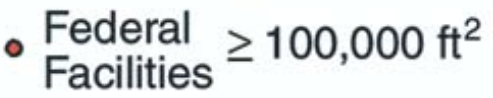

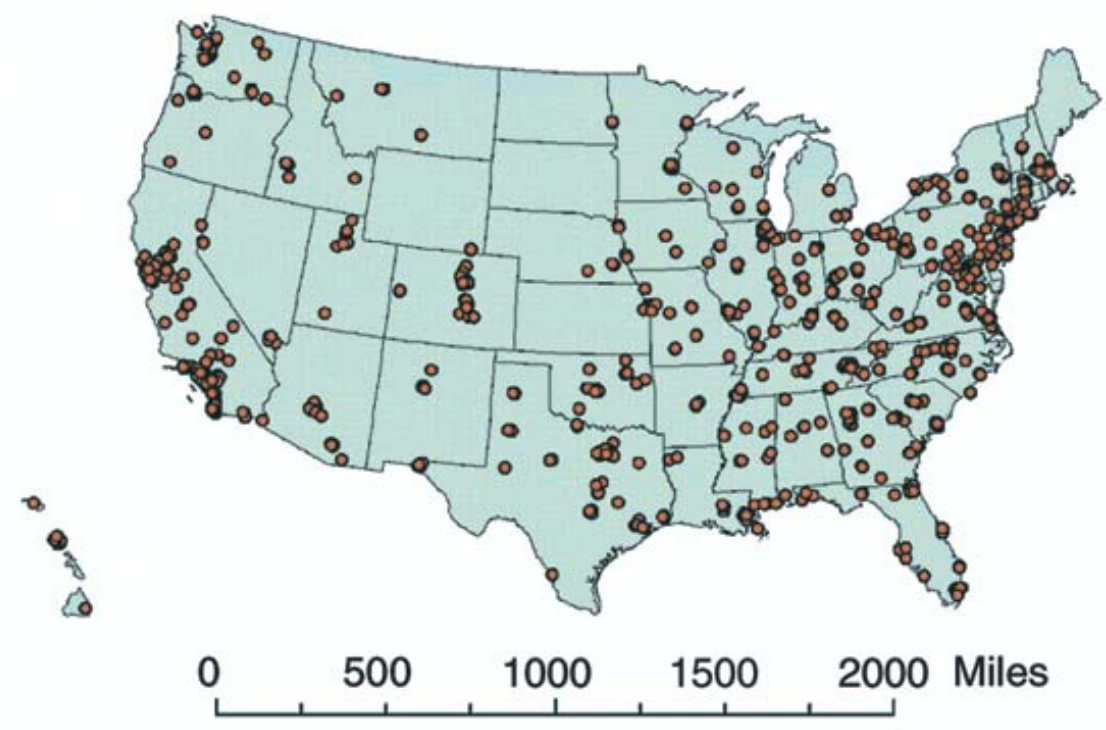

Figure A1. Federal facilities within 15 miles of a candidate landfill (Source: http://www1.eere.energy.gov/femp/pdfs/bamf_landfill.pdf).

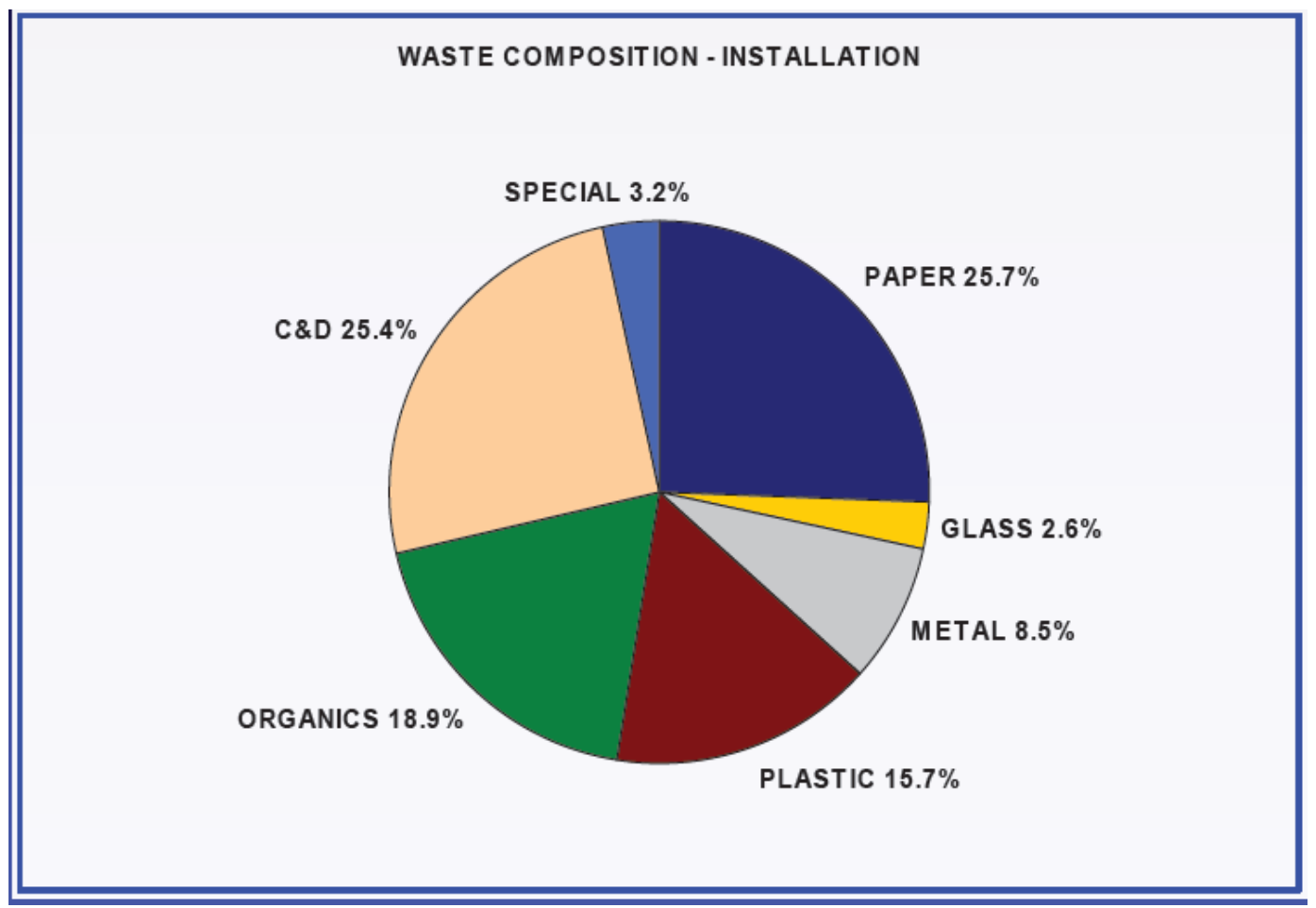

Figure A2. Solid Waste Composition-Aberdeen Proving Ground (Source: Solid Waste Characterization at an Army Facility, USACHPPM, Ground Water and Solid Waste Program 2007). 


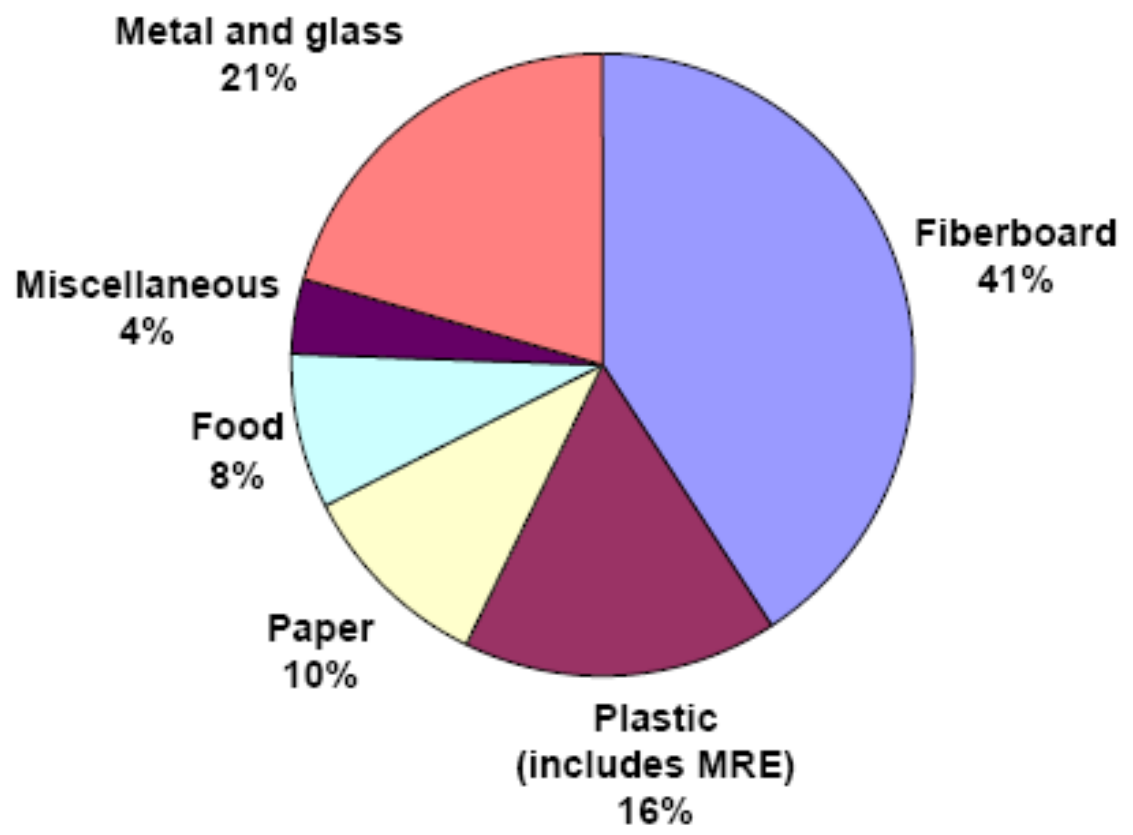

Figure A3. Solid waste stream characterization for deployed Army units (Source: An Analysis of the Energy Potential of Waste in the Field, LMI, February 2004).

On average a U.S. soldier produces $7.2 \mathrm{lb}$ of waste per day. In a deployed situation, this waste is usually transported off site and either burned or buried.

\section{Energy Recovery from Waste-Today}

There are waste-to-energy projects currently underway and contributing to DoD energy objectives. In FY2007, the DoD Energy Management Report identified two installations: (1) Eielson Air Force Base and (2) Hill Air Force Base that were generating energy from waste.

The Eielson Air Force Base system processed over 560 tons of paper products in the base's central heat and power plant, which provided 7.820 million Btu of energy (program currently suspended because the pellet plant is inoperable). As was stated above, thermal energy does not count toward the EPACT 2005 renewable energy requirement, but does count towards E.O. 13423 requirements. 
The second installation cited in the report was Hill Air Force Base, which generated 2.1 MWh of electricity from landfill gas and has plans to expand to 3.2 MW.

The report also referenced Dyess AFB, which is pursuing a 5.5MW municipal solid waste energy plant.

The focus on solid waste management within the DoD has been waste diversion through integrated waste management practices such as reduce, reuse, recycle programs. This focus has led to a cost savings in FY2007 of $\$ 180$ million. It is important that the focus remain on waste minimization/ diversion and seek opportunities to address the remaining waste through energy recovery. (Note the solid waste management hierarchy shown in Figure A4.) This will focus the discussion on appropriate sizing and end-use of the energy.

\section{SCALE- INSTALLATION and DEPLOYABLE}

It is necessary when considering waste to energy that an evaluation be done to determine the proper scale of the system and the end use for the energy (electrical or thermal or combined heat and power). There is greater flexibility when considering a waste-to-energy system for an installation. Depending on waste resource availability, quantity, and energy needs, the system can be scaled within the $1 \mathrm{MW}$ and up range.

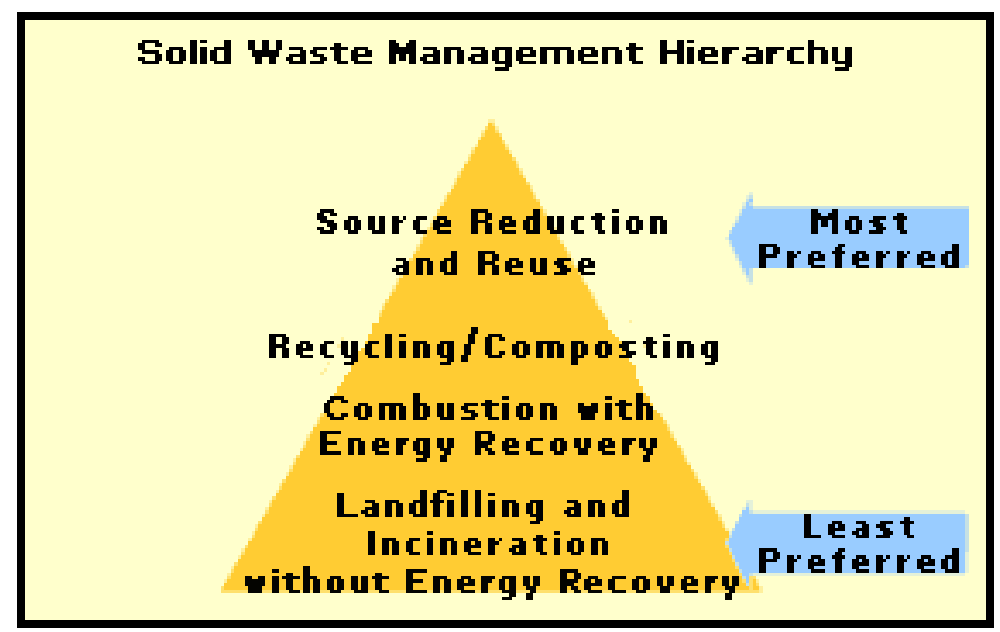

Figure A4. Solid waste management hierarchy (Source: Environmental Protection Agency).

* Office of the Under Secretary of Defense for Acquisition, Technology and Logistics. January 2008. Department of Defense Annual Energy Management Report. 01 May 2008, http://www.acq.osd.mil/ie/irm/Energy/energymgmt_report/fy07/DoD-Narrative-Final.pdf 
However, when considering deployable systems, these systems will generally be scaled between the $60 \mathrm{~kW}$ to $1 \mathrm{MW}$ range for ease of deployment, transport, set up, and tear down and resource quantity. The amount of available waste will drive the scale of the system and the appropriate technology.

Figures A5 and A6 show that there are three types of conversion pathways that biomass/ waste can undergo depending on what the end product is to be i.e., heat, power, liquid fuels or chemicals.

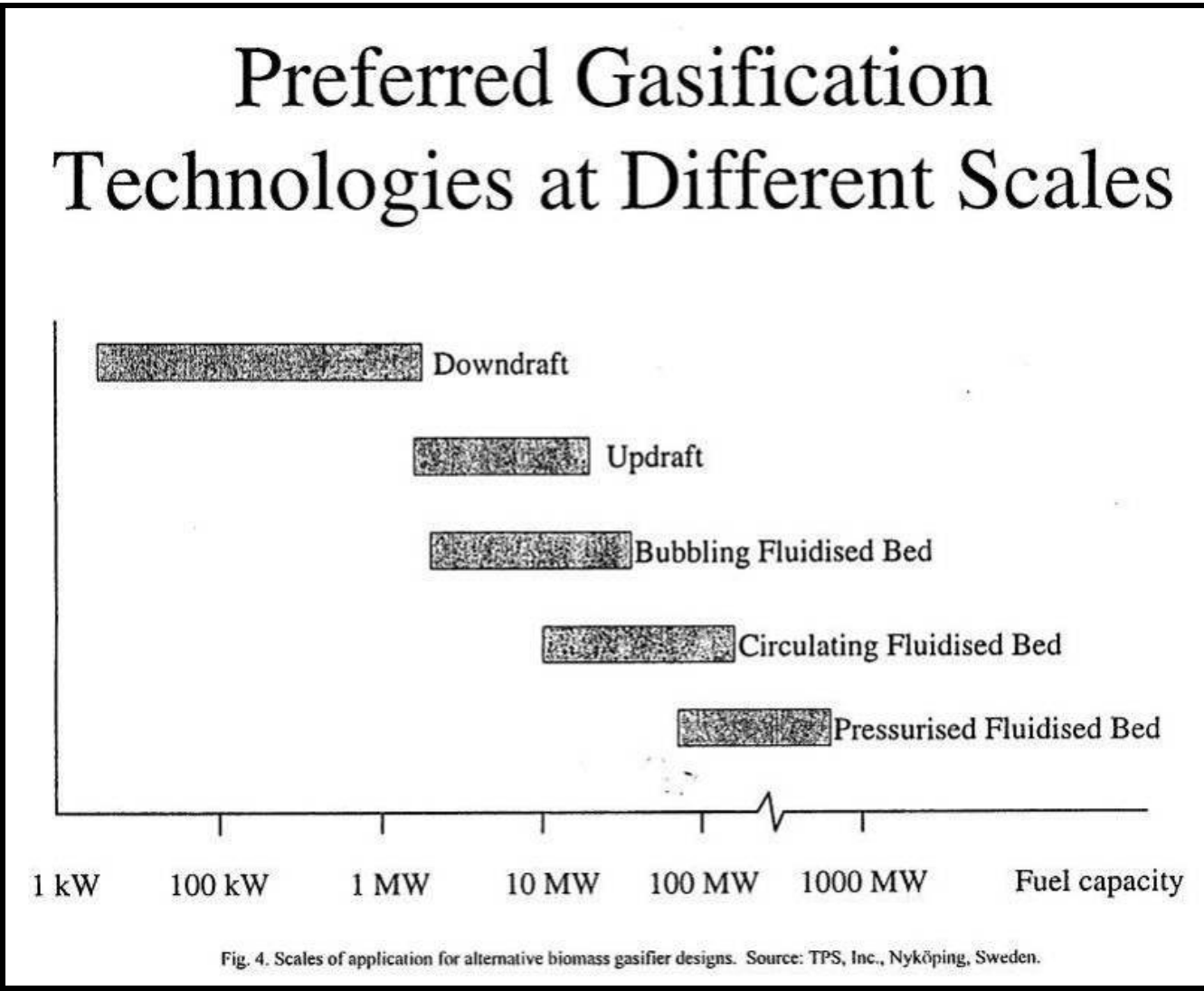

Figure A5. Preferred gasification technologies at different scales (Source: Larson, Eric D., “Small-Scale Gasification-Based Biomass Power Generation," January 1998.). 


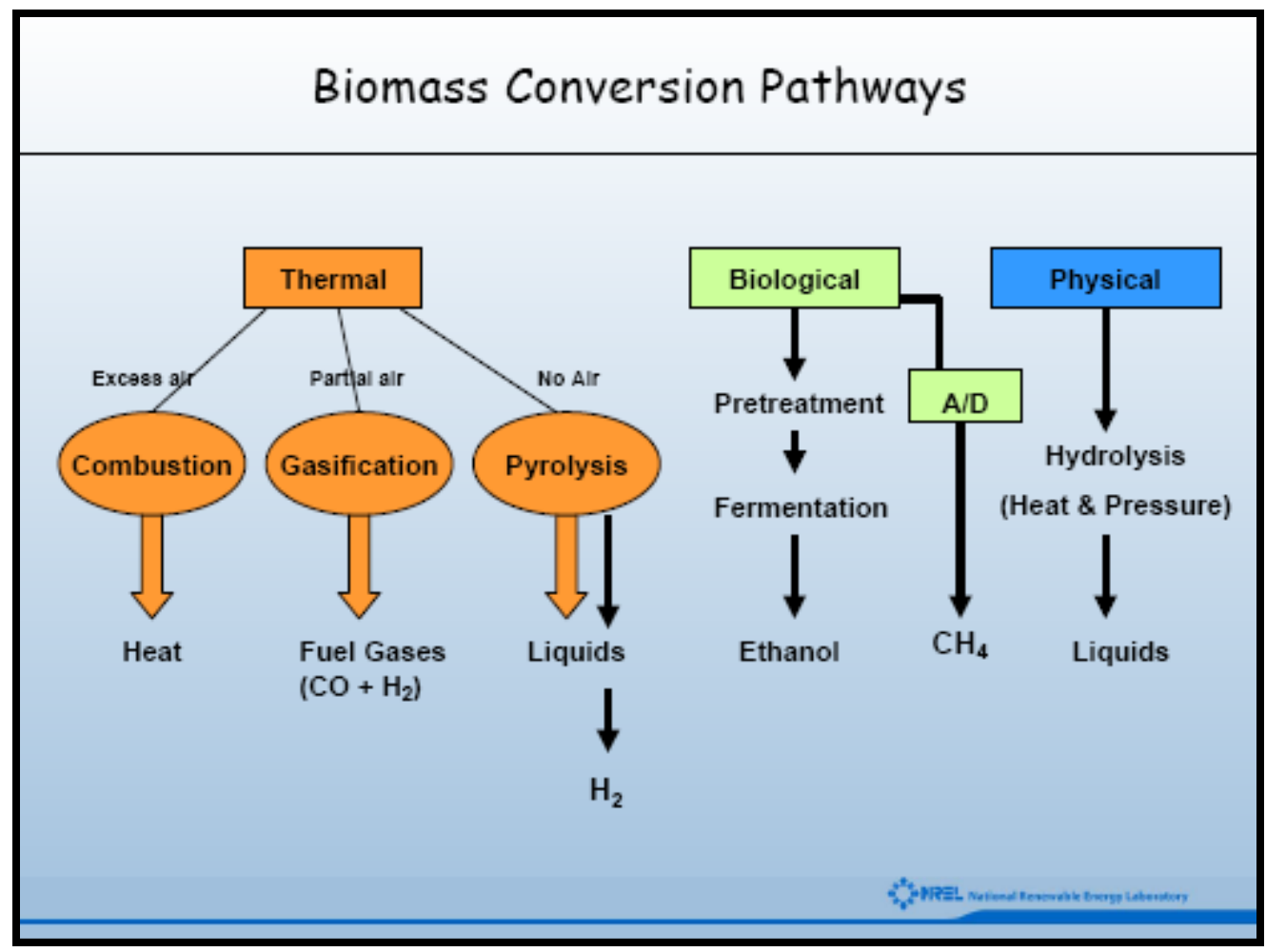

Figure A6. Biomass conversion pathways (Source: National Renewable Energy Laboratory).

\section{Thermochemical}

Thermochemical conversion technologies convert biomass and its residues to fuels, chemicals, and power using gasification and pyrolysis technologies. Gasification-heating biomass with about one-third of the oxygen necessary for complete combustion-produces a mixture of carbon monoxide and hydrogen, known as syngas. Pyrolysis - heating biomass in the absence of oxygen-produces a liquid pyrolysis oil. Both syngas and pyrolysis oil can be used as fuels that are cleaner and more efficient than the solid biomass. Both can also be chemically converted to other valuable fuels and chemicals.

\section{Combustion}

For many, the immediate reaction to waste to energy is that the concept centers on the idea of incineration or combustion, which holds a negative connotation associated with visible emissions and the release of toxic pollutants. Therefore, it is important to understand the differences between combustion and gasification. Although, it is also important to note that the 
United States has about 89 operational MSW-fired power generation plants generating approximately 2,500 megawatts of electricity. ${ }^{*}$

"Both gasification and combustion processes convert carbonaceous material to gases. Gasification processes operate in the absence of oxygen or with a limited amount of oxygen, while combustion processes operate with excess oxygen. These two processes produce two different gas compositions. Combustion gas is generally comprised of $\mathrm{CO}_{2}, \mathrm{H}_{2} \mathrm{O}, \mathrm{SO}_{2}, \mathrm{NOX}$ and particulates and when cleaned is primarily $\mathrm{CO}_{2}$ and $\mathrm{H}_{2} \mathrm{O}$. While gasification produces a gas generally comprised of $\mathrm{H}_{2}, \mathrm{CO}, \mathrm{H}_{2} \mathrm{~S}, \mathrm{NH}_{3}$ and particulates and when cleaned consists primarily of $\mathrm{H}_{2}$ and $\mathrm{CO}$. The resulting byproducts are also quite different, byproducts of gasification are typically nonhazardous material whereas combustion byproducts are treated as hazardous waste." ${ }^{\dagger}$

"Combustion, or incineration, is a widely-accepted waste treatment option with many benefits. Combustion reduces the volume of waste that must be disposed in landfills, and can reduce the toxicity of waste. Combustion can also result in significant energy and material recovery - waste combustion can be used to generate energy, and in some cases, the ash that is generated can be recovered and beneficially-used (e.g., as landfill cover, or as aggregate in asphalt concrete). Air emissions from both municipal waste combustors and hazardous waste combustion units are regulated under the Clean Air Act (CAA). In addition, combustion ash must be managed as potentially hazardous waste under the purview of the Resource Conservation and Recovery Act (RCRA), and must meet all applicable Federal and state regulations for disposal.” ${ }^{\ddagger}$

\section{Gasification}

Gasification is the process in which a solid fuel is converted into a gas. Production of a clean fuel gas makes a wide variety of power options available. ${ }^{\S}$ There are currently four types of gasifier available for

\footnotetext{
* Environmental Protection Agency. Solid Waste Combustion/Incineration. 02 May 2008. http://www.epa.gov/epaoswer/non-hw/muncpl/landfill/sw_combst.htm

$\dagger$

Rezaiyan, John and Cheremisinoff, Nicholas P., Gasification Technologies-A Primer for Engineers and Scientists, Taylor \& Francis Group, 2005, Boca Raton, FL. 02 May 2008. Google Books, http://books.google.com/books?hl=en\&id=GdOP5mrKT-

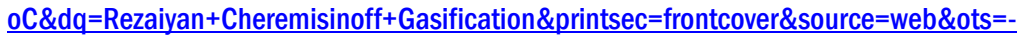
wcFnyiyi8\&sig=e_eRzKxrZmApJ7YycSYPSS60EhQ

‡Environmental Protection Agency. Solid Waste Combustion/Incineration. 02 May 2008, http://www.epa.gov/epaoswer/non-hw/muncpl/landfill/sw_combst.htm

$\S U . S$. Department of Energy, Energy Efficiency and Renewable Energy, Glossary of Energy Related Terms.
} 
commercial use: (1) counter-current fixed bed, (2) co-current fixed bed, (3) fluidized bed, and (4) entrained flow.

The counter-current fixed bed ("up draft") gasifier consists of a fixed bed of carbonaceous fuel (e.g., coal or biomass) through which the "gasification agent" (steam, oxygen, and/ or air) flows in counter-current configuration. The ash is either removed dry or as a slag. The slagging gasifiers require a higher ratio of steam and oxygen to carbon to reach temperatures higher than the ash fusion temperature. The nature of the gasifier means that the fuel must have high mechanical strength and must be non-caking so that it will form a permeable bed, although recent developments have reduced these restrictions to some extent. The throughput for this type of gasifier is relatively low. Thermal efficiency is high as the gas exit temperatures are relatively low. However, this means that tar and methane production is significant at typical operation temperatures, so product gas must either be extensively cleaned before use, or be recycled to the reactor.

The co-current fixed bed ("down draft") gasifier is similar to the counter-current type, but the gasification agent gas flows in co-current configuration with the fuel (downwards, hence the name "down draft gasifier"). Heat needs to be added to the upper part of the bed, either from external heat sources, or by combusting small amounts of the fuel. The produced gas leaves the gasifier at a high temperature, and most of this heat is often transferred to the gasification agent added in the top of the bed, resulting in an energy efficiency on level with the counter-current type. Since all tars must pass through a hot bed of char in this configuration, tar levels are much lower than the counter-current type.

In the fluidized bed reactor, the fuel is fluidized in oxygen and steam or air. The ash is removed dry or as heavy agglomerates that defluidize. The temperatures are relatively low in dry ash gasifiers, so the fuel must be highly reactive; low-grade coals are particularly suitable. The agglomerating gasifiers have slightly higher temperatures, and are suitable for higher rank coals. Fuel throughput is higher than for the fixed bed, but not as high as for the entrained flow gasifier. The conversion efficiency can 
be rather low due to elutriation of carbonaceous material. Recycle or subsequent combustion of solids can be used to increase conversion. Fluidized bed gasifiers are most useful for fuels that form highly corrosive ash that would damage the walls of slagging gasifiers. Biomass fuels generally contain high levels of corrosive ash.

In the entrained flow gasifier, a dry pulverized solid, an atomized liquid fuel, or a fuel slurry is gasified with oxygen (much less frequently, with air) in co-current flow. The gasification reactions take place in a dense cloud of very fine particles. Most coals are suitable for this type of gasifier because of the high operating temperatures and because the coal particles are well separated from one another. The high temperatures and pressures also mean that a higher throughput can be achieved, however thermal efficiency is somewhat lower as the gas must be cooled before it can be cleaned with existing technology. The high temperatures also mean that tar and methane are not present in the product gas; however the oxygen requirement is higher than for the other types of gasifiers.

All entrained flow gasifiers remove the major part of the ash as a slag as the operating temperature is well above the ash fusion temperature. A smaller fraction of the ash is produced either as a very fine dry fly ash or as a black colored fly ash slurry. Some fuels, in particular certain types of biomasses, can form slag that is corrosive for ceramic inner walls that serve to protect the gasifier outer wall. However some entrained bed type of gasifiers do not possess a ceramic inner wall, but have an inner water or steam cooled wall covered with partially solidified slag. These types of gasifiers do not suffer from corrosive slags. Some fuels have ashes with very high ash fusion temperatures. In this case, mostly limestone is mixed with the fuel prior to gasification. Addition of a little limestone will usually suffice for the lowering the fusion temperatures. The fuel particles must be much smaller than for other types of gasifiers. This means the fuel must be pulverized, which requires somewhat more energy than for the other types of gasifiers. By far, the most energy consumption related to entrained bed gasification is not the milling of the fuel, but the production of oxygen used for the gasification.*

\footnotetext{
* Wikipedia. Gasification. Wikipedia contributors. 29 April 2008.Wikipedia, The Free Encyclopedia. 02 May 2008, http://en.wikipedia.org/w/index.php?title=Gasification\&oldid=209119869
} 


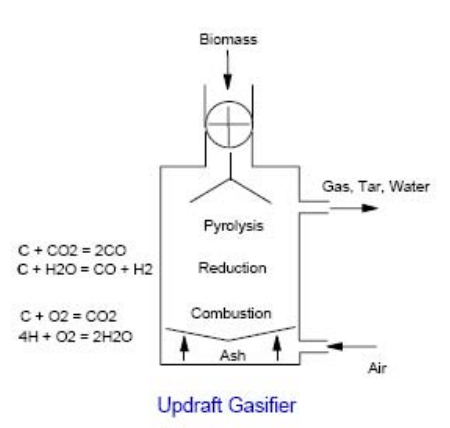

Figure 1: Gasifier Types
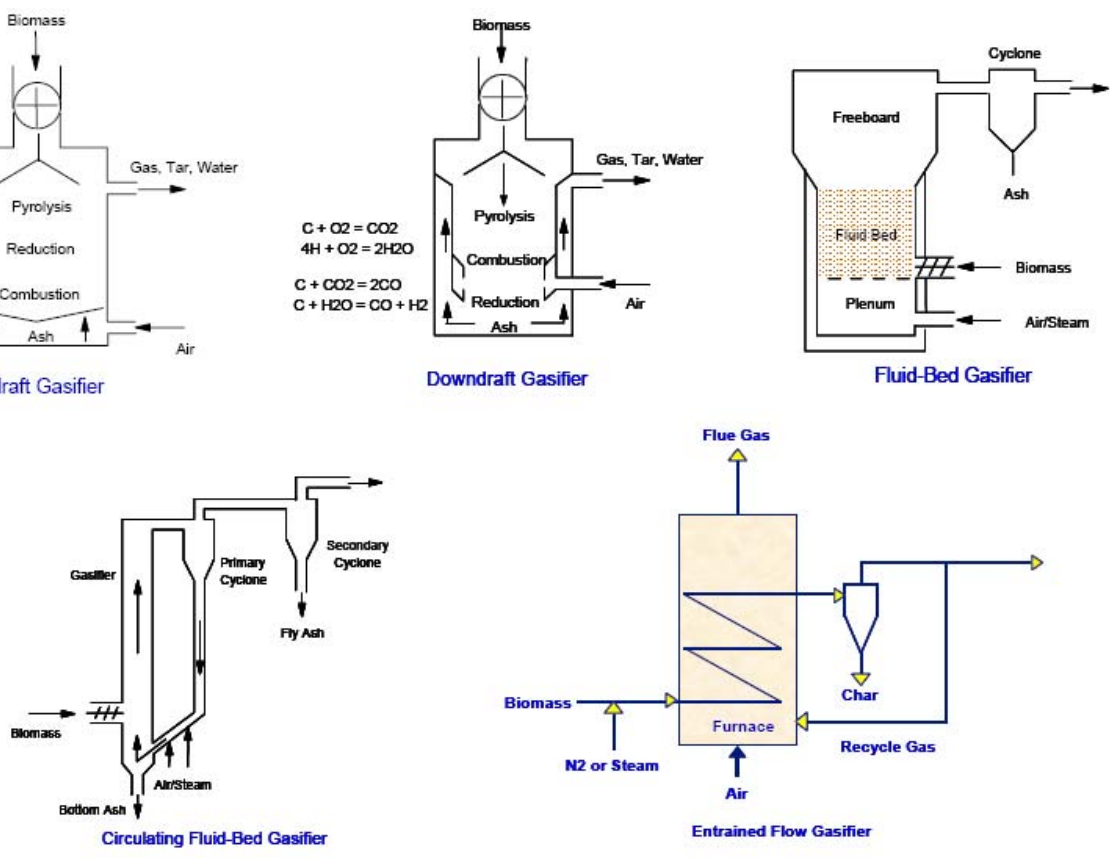

Figure A7. Gasifier types (Source: National Renewable Energy Laboratory).

Pyrolysis

The transformation on a compound or material into one or more substances by heat alone (without oxidation). Often called destructive distillation. Pyrolysis of biomass is the thermal degradation of the material in the absence of reacting gases, and occurs prior to or simultaneously with gasification reactions in a gasifier. Pyrolysis products generally consist of gases, liquids, and char. The liquid fraction of pyrolysized biomass consists of an insoluble viscous tar, and pyroligneous acids (acetic acid, methanol, acetone, esters, aldehydes, and furfural). The distribution of pyrolysis products varies depending on the feedstock composition, heating rate, temperature, and pressure.

\section{Bioconversion}

The conversion of one form of energy into another by the action of plants or microorganisms. The conversion of biomass to ethanol, methanol, or methane.

\footnotetext{
* U.S. Department of Energy, Energy Efficiency and Renewable Energy, Glossary of Energy Related Terms. 30 April 2008, http://www.eere.energy.gov/consumer/information_resources/index.cfm/mytopic=60001\#G
}

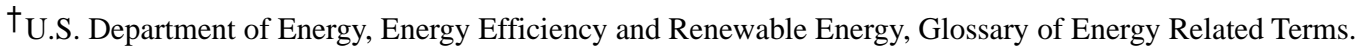




\section{Fermentation}

The decomposition of organic material to alcohol, methane, etc., by organisms, such as yeast or bacteria, usually in the absence of oxygen.

\section{Anaerobic Digestion}

The complex process by which organic matter is decomposed by anaerobic bacteria. The decomposition process produces a gaseous byproduct often called "biogas" primarily composed of methane, carbon dioxide, and hydrogen sulfide.

\section{Case studies}

\section{Hill Air Force Base Landfill Gas to Energy*}

\section{Plant Commissioned January 2005}

- $\quad$ First 2 years produced 13.2 million $\mathrm{kWh}$

- Saved \$635K in purchased electrical cost

- Added $3^{\text {rd }}$ generator increasing production to $2.1 \mathrm{MW}$ (Dec 2007)

Challenges with waste to energy:

- feedstock handling/pre-processing/transportation

- feedstock (moisture content, characterization, quantity/ consistency)

- technology scale-up/down

- producer/syngas gas cleanup

- by-product (ash/char) handling and disposal

- public perception

- dispatch of electricity (siting plant near transmission lines, interconnect issues)

- financing. 


\section{Reference links}

\section{Feedstock characterization}

Logistics Management Institute. 2004. An analysis of the energy potential of waste in the field (DRP30T1). Accessed 05 May 2008, http://www.combatfeeding.org/sbir2005/files/a05-037/DRP30T1.pdf

Ruppert, Bush, Geiman Verdonik, and Hughes Harrison Associates, Inc. Baltimore, MD. August 2004. Force provider solid waste characterization study (NATICK/TR04/ 017). Accessed 05 May 2008, http://stinet.dtic.mil/cgibin/GetTRDoc?AD=ADA427565\&Location=U2\&doc=GetTRDoc.pdf

Schafstall, Tim. Solid waste characterization at an Army facility. Location: Aberdeen Proving Ground, MD, U.S. Army Center for Health Promotion and Preventative Medicine, Ground Water and Solid Waste Program. Accessed 05 May 2008, http://proceedings.ndia.org/isem2007/3813_Schafstall.pdf

\section{Technology}

Bain, Amos, and Perlack Downing. 2008. Highlights of biopower technical assessment: State of the technology and industry. (NREL/TP-510-33502). National Renewable Energy Laboratory, Technical Report. Accessed 05 May 2008, http://www.nrel.gov/docs/fy03osti/33502.pdf

Bain, R. 2000. Small modular biopower initiative phase I: Feasibility studies executive summaries. (NREL/TP-570-27592). National Renewable Energy Laboratory, Technical Report. Accessed 05 May 2008, http://www.nrel.gov/docs/fy00osti/27592.pdf

Larson, Eric D. 1998. Small-scale gasification-based biomass power generation. Prepared for the Biomass Workshop, Changchun, J ilin Province China, 12-13 J anuary 1998, http://www.princeton.edu/ energy/publications/pdf/1998/Small_scale_\%20gasification.pdf

Niessen, Walter R., Charles H. Marks, and Robert E. Sommerlad. 1996. Evaluation of gasification and novel thermal processes for the treatment of municipal solid waste. (REL/TP-430-21612), National Renewable Energy Laboratory. Accessed 02 May 2008, http://www.osti.gov/bridge/servlets/purl/101642857CBnFx/webviewable/10164285.PDF

Rensfelt, Erik, and Anders Ostman. Undated. "Sub-task 6-Gasification of Waste Summary and Conclusions of Twenty-Five Years of Development, IEA Biomass Agreement" Accessed 02 May 2008, http://media.godashboard.com/gti/IEA/WastelEA25years.pdf

Timpe, Mann. 2000. Gasification for distributed generation- Task 3.5 final topical report, May 1, 1999-March 31, 2000. National Energy Technology Laboratory, UND EERC-DOE. Accessed 02 May 2008, http://www.osti.gov/bridge/servlets/purl/824977CdHCRS/native/824977.pdf

URS Corporation. 2005. Conversion technology evaluation report, appendices. Report prepared for City of Los Angeles, Accessed 02 May 2008, http://www.ladpw.com/epd/tf/Attachments/SubCommittee\%20Attachments/CT_Eval_Rpt_Ap p.pdf\#search=\%22gasifying\%20tires $\% 20$ lime $\% 22$ 
URS Corporation. 2005. Summary report: Evaluation of alternative solid waste processing technologies. Report Prepared for City of Los Angeles, http://www.lacity.org/SAN/alternative-technologies-summary-report.pdf

\section{Policy}

2007 Federal Energy Management Program (FEMP) Renewable Energy Requirement Guidance for EPACT 2005 and Executive Order 13423 Final. 2008. Prepared by the U.S. Department of Energy, Office of Energy Efficiency and Renewable Energy Federal Energy Management Program. Accessed 05 May 2008, http://www1.eere.energy.gov/femp/pdfs/epact05_fedrenewenergyguid.pdf

Army Energy Campaign http://army-energy.hqda.pentagon.mil/programs/plan.asp

Department of Defense Key Directives, http://army-energy.hqda.pentagon.mil/policies/key_directives.asp

Executive Order 13423-Strengthening Federal Environmental, Energy, and Transportation Management. 2007. Office of the Federal Environmental Executive, Federal Register. Accessed 05 May 2008, http://ofee.gov/eo/E0_13423.pdf and http://ofee.gov/eo/eo13423_main.asp

Office of the Biomass Program, Energy Efficiency and Renewable Energy, U.S. Department of Energy. 2008. Biomass multi-year program plan, http://www1.eere.energy.gov/biomass/pdfs/biomass_program_mypp.pdf http://www.nrel.gov/docs/fy00osti/28330.pdf

U.S. Department of Energy, Federal Energy Management Program. Energy Policy Act 2005. Accessed 05 May 2008, http://www1.eere.energy.gov/femp/about/legislation_epact_05.html

\section{Funding}

Energy Savings Performance Contracts (ESPC)

http://army-energy.hqda.pentagon.mil/policies/guidance.asp

Enhanced Use Leasing (EUL)

http://eul.army.mil// 


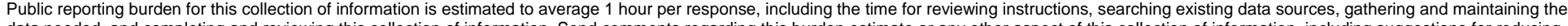

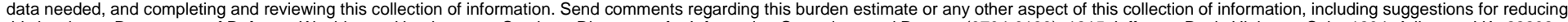

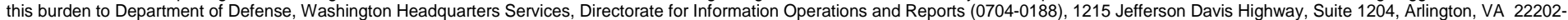

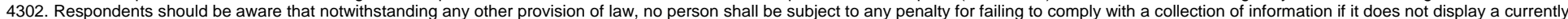
valid OMB control number. PLEASE DO NOT RETURN YOUR FORM TO THE ABOVE ADDRESS.
1. REPORT DATE (DD-MM-YYYY)
2. REPORT TYPE
3. DATES COVERED (From - To)

17-08-2008

Final

4. TITLE AND SUBTITLE

Proceedings of the 1st Army Installation Waste to Energy Workshop

5a. CONTRACT NUMBER

5b. GRANT NUMBER

5c. PROGRAM ELEMENT

6. AUTHOR(S)

Franklin H. Holcomb, René S. Parker, Thomas J . Hartranft, Kurt Preston, Harold R. Sanborn, and Philip

J. Darcy

5d. PROJECT NUMBER

5e. TASK NUMBER

5f. WORK UNIT NUMBER

8. PERFORMING ORGANIZATION REPORT NUMBER

U.S. Army Engineer Research and Development Center (ERDC)

Construction Engineering Research Laboratory (CERL)

PO Box 9005,

Champaign, IL 61826-9005

ERDC/ CERL TR-08-11

9. SPONSORING I MONITORING AGENCY NAME(S) AND ADDRESS(ES)

10. SPONSOR/MONITOR'S ACRONYM(S)

11. SPONSOR/MONITOR'S REPORT NUMBER(S)

12. DISTRIBUTION / AVAILABILITY STATEMENT

Approved for public release; distribution is unlimited.

\section{SUPPLEMENTARY NOTES}

\section{ABSTRACT}

first-ever waste to energy (WTE) workshop gathered Army environmental and energy subject matter experts to explore WTE at the installation and forward operating level. Historically, the Army environmental community has focused on solid waste disposal and the energy community on energy efficiency and power delivery, with no orchestrated integration of the two. The Energy Branch of the U.S. Army Engineer Research and Development Center, Construction Engineering Research Laboratory has been investigating WTE opportunities, and has found little Army analysis on WTE system providers' many claims. The goals of this workshop were to share information, spread visibility on current efforts, explore the potential of WTE technologies for military installations, and potentially launch working groups to further implementation of installation WTE technologies. The Army has many requirements, goals, and recommendations applicable to DoD installations, facilities, and energy. WTE technologies are being developed for deployed forces, and have been used somewhat at fixed installations. Studies have focused on the types, amounts, and "burdened" costs of battlefield wastes, but less so on installation waste streams. Workshop participants concluded that greater use or development of WTE technologies may help fixed installations meet requirements and goals, but data is lacking to adequately characterize the potential.

\section{SUBJECT TERMS}

waste management waste to energy (WTE) energy efficient

workshop

\begin{tabular}{|c|c|c|}
\hline \multicolumn{3}{|c|}{ 16. SECURITY CLASSIFICATION OF: } \\
\hline $\begin{array}{l}\text { a. REPORT } \\
\text { Unclassified }\end{array}$ & $\begin{array}{l}\text { b. ABSTRACT } \\
\text { Unclassified }\end{array}$ & $\begin{array}{l}\text { c. THIS PAGE } \\
\text { Unclassified }\end{array}$ \\
\hline
\end{tabular}

NSN 7540-01-280-5500

\begin{tabular}{|c|c|c|}
\hline 17. LIMITATION & $\begin{array}{c}\text { 18. NUMBER } \\
\text { OF ABSTRACT }\end{array}$ & \\
OAR PAGES & 56 & \\
& &
\end{tabular}

Standard Form 298 (Rev. 8-98)

Prescribed by ANSI Std. 239.1 